\title{
An Evaluation of the English Language Teaching Textbooks within the
}

\section{Context of Culture of Thinking ${ }^{1}$}

\author{
Sibel GÜZEL YÜCE², Gamze EMIR ${ }^{3}$
}

\begin{abstract}
The sociocultural approach has recently been focused on teaching thinking skills and considering the rapidly changing information age and lifelong learning skills, it can be said that culture-based thinking instruction has become more popular. The literature illustrates few but various studies regarding the contribution of the culture of thinking in different projects. In that vein, this study seeks to examine English Language Teaching (ELT) Moonlight 8th grade students' book and workbook which were distributed by the Ministry of National Education and taught in state schools within the context of the culture for thinking. The target textbooks were analyzed through document analysis in the framework of qualitative research designs. Tishman, Perkins, and Jay (1995)'s framework of the culture of thinking was taken as a basis for examining the target textbooks regarding culture of thinking and main themes have been shaped. The findings of the study concluded that along with the activities supporting the culture of thinking in regard to the language of thinking, mental management, strategic attitude, and transfer, various activities and activity expressions were emphasized to have a risk to overshadow the findings of supporting the culture of thinking.
\end{abstract}

Keywords: Teaching thinking skills, culture of thinking, English language teaching, curriculum, textbooks

\footnotetext{
${ }^{1}$ This study has been presented as an oral presentation at 27. International Conference on Educational Sciences (ICES/UEBK-2018) held on 18-22 April 2018, Antalya, Turkey. Ethics committee approval was received for this research from Hatay Mustafa Kemal University on 08.08.2019 with the number 05.

2 Hatay Mustafa Kemal University, Faculty of Education, Department of Educational Sciences, e-mail: sguzel@ mku.edu.tr, ORCID: 0000-0002-9816-1624

3 Hatay Mustafa Kemal University, Faculty of Education, Department of English Language Teaching, e-mail: gamzeemir@mku.edu.tr, ORCID: 0000-0002-9705-9767
} 
AJESI - Anadolu Journal of Educational Sciences International, 2020; 10(1): 583-628

DOI: 10.18039/ajesi.682060

\section{Introduction}

How and at what level the link between language and thinking is still a matter of debate between both linguists and educational scientists (Feuerstein, et. al., 1980; Rogoff, 1990; Vygotsky, 1994, Costa and Marzano, 2001; Piaget, 2002). The relationship between language and thinking in the fields of linguistics and educational sciences are the most discussed topics. Scientists, however, agree that language and thought cannot be separated from each other. Supporting the close relationship between language and thought, Brown (2007, p. 77) argues that "language helps to shape thinking and that thinking helps to shape language". Along with stating the interaction between language and thought, he adds culture as an integral part of that interaction. In that vein, when considering culture as a dynamic system effecting a person's worldview, sell-identity, and systems of thinking, acting, feeling, and communication, language can be seen the most visible and available expression of any culture (Brown, 2007, p. 194; Costa \& Marzano, 2001; Matsumoto, 2000, p. 24; Nisbett, 2003; Witkin \& Berry, 1975).

Although discussions about the relationship between language and thinking remain up to date among linguists, the vast majority of educational reforms in the world focus on teaching thinking processes such as critical thinking, creative thinking, metacognition, problem-solving and decision making (Marzano et. al., 1988). In other words, the teaching of thinking processes and skills is at the center of educational reforms, curriculums and educational goals (Resnick \& Resnick, 1992; Vygotsky, 1994; Fisher, 1995; Tishman, Perkins \& Jay, 1995; Costa \& Marzano, 2001; Ritchart, 2002; Topping \& Bryce 2004; Wegerif, 2006; Costa, 2008; Zohar, 2013, Dilekli ve Tezci, 2016; Li, 2016, Zohar \& Cohen, 2016, McGuinness, 2018).

The thinking processes and skills are not only a popular area of linguistics and educational sciences, but also work in philosophy, cognitive psychology, and neurology. It is necessary to say that the thinking processes and skills have even a cultural dimension. (Wertsch, 1985; Nuthall, 1999). It should not be anticipated that the act of thinking which plays a leading 
AJESI - Anadolu Journal of Educational Sciences International, 2020; 10(1): 583-628 DOI: 10.18039/ajesi.682060

role in the individual's personal, academic, and social development will be built up and developed by itself especially during the education and training process. Thinking skills are actually shaped by our cultural environments and it guides our decision-making process through deciding on which and how the information we process and evaluate. Therefore, most decisions can be seen as 'cultural decisions' because they generally influenced by individuals' social and cultural context (Brown, 2007, p. 194; Güss, \& Robinson, 2004; Weber \& Morris, 2010).

The teaching of thinking skills is a difficult and controversial subject, although it is the focus of different disciplines. Literature includes various approaches to the teaching of thinking skills with the aim of contributing and supporting individual beings to become good thinkers (Feuerstein et. al, 1980; Lipman, 1982; De Bono, 1983; Marzano et. al., 1988; Rogoff, 1990; Tishman, Perkins \& Jay, 1995; Costa \& Marzano, 2001; Ritchhart, 2002; Costa, 2008). Some of the most prominent examples of thinking skills programs are mentioned below under these headings: Separate programs which are direct skill-based thinking instruction; subject-based programs that are based on teaching of thinking skills in a course context, Infusion programs that can be infused across the curriculum-thinking curriculum, and Multi-method programs in which the following three approaches could be placed more than one of the above divisions (Trickey \& Topping, 2004, 366-367). In recent years, sociocultural approach, namely infused across the curriculum- infusion programs, has been focused on teaching thinking skills (Rogoff, 1990; Vygotsky, 1994; McGuinness, 1999; Tishman, Perkins and Jay, 1995; Ritchart, 2002; Mercer \& Littleton, 2007; Wegerif, 2010). In other words, considering the rapidly changing information age and lifelong learning skills, it can be said that culture-based thinking instruction has become more popular.

One of the socio-cultural approach studies is the thinking culture approach (Tishman, Perkins, and Jay, 1995; Ritchart, 2002) The term 'culture of thinking' is defined as "a classroom environment in which several forces, which are language, values, expectations, and habits, work 
AJESI - Anadolu Journal of Educational Sciences International, 2020; 10(1): 583-628

DOI: 10.18039/ajesi.682060

together to express and reinforce the enterprise of good thinking” (Tishman, Perkins \& Jay, 1995, p. 2). Similarly, Ritchhart (2002) argues that culture of thinking refers to "a place where a group's collective as well as individual thinking is valued, visible, and actively promoted as part of the regular, day-to-day experience of all group members" (p. 32). It provides a substantive interpretation of the thinking process and a conducive and positive environment that promotes learning and thinking skills (Gushchin, 2015; Halpern, 2003; Tishman, Perkins, et al., 1995; Ritchhart, 2002). In this vein, the culture of thinking is required to be constructed in classrooms to ensure effective problem solving, thoughtful decision making, and lifelong learning (Tishman, Perkins and Jay, 1995).

In the culture of thinking approach, different sub-dimensions (language of thinking, thinking dispositions, mental management, strategic spirit, higher order knowledge and transfer) and different forces (environment, expectations, opportunities, modelling, giving thinking time, thinking routines, conversation, and interactions) that shape the culture of a group are discussed (Tishman, et al., 1995; Ritchart, 2002; Ritchart, 2007). It also benefitted various cultural forces that work together like language, values, expectations and habits in order to promote good thinking. (Ritchhart, 2002; Tishman, Perkins \& Jay, 1995).

In this approach, the language of thinking has an important place in the culture of thinking. However, the culture of thinking is considered as a sub-dimension in some studies (Tishman, Perkins \& Jay, 1995) and as a cultural force in some studies (Ritchart, 2002; Ritchart, 2007). Language of thinking which is one of the aspects of the culture of thinking and is one of the cultural forces plays an intermediary role between teachers and students in a classroom environment in making thinking apparent and teaching thinking skills. In other words, classrooms are considered as a site of the culture of thinking which promotes students' critical thinking abilities and dispositions, and language is considered a crucial and essential tool for that purpose (Costa \& Marzano, 2001). The dispositions in the culture of thinking are an 
AJESI - Anadolu Journal of Educational Sciences International, 2020; 10(1): 583-628

DOI: 10.18039/ajesi.682060

important dimension and the most difficult area to be studied (Ritchart, 2002). Mental management is more of a term used to mean metacognition (Tishman et, al., 1995). Metacognition refers to the knowledge and control that we have over our cognitive processes (Karbalaei, 2011, p.6). Metacognition is a powerful construct in today's educational setting, and its principled teaching can instill a sense of independence and autonomy into learners (Mahdavi, 2014, p.534). In many sources, it is defined as thinking of thinking (Doğanay, 1997). The strategic attitude is that the individual manages the thinking task by following the strategy. It is in a close relationship with mental management. High-level knowledge is also argued to be the other dimension of the culture of thinking, focusing on how knowledge is produced in the taught discipline. The final dimension is the transfer which refers to making connections when students are learning or thinking (Tishman, Perkins and Jay, 1995).

Some contributions were made different projects to the create culture of thinking. For example, in 1990s, Singapore implemented “Thinking Schools, Learning Nation”, formal schools have been transformed into "Smart Schools" in Malaysia and "Thoughtful Schools" in Brunei Darussalam (Abdul Shukor, 2001; Chang, 2001; and Sim, 2001). The most powerful side of those approaches is to have the power of improving the hidden curriculum along with the formal curriculum. Literature also includes a number of studies contributed to improving teaching skills (Bourke, 2004; Golding, 2010; See, 1998; Tam, 2018; Yong, 2003). Similarly, teaching foreign language skills are associated with thinking, process, and skills and thinking skills also have an important place in improving and promoting language skills (Brown, 2007; Karadüz, 2010). However, it is challenging in foreign language teaching considering the fact learning a second language refers to learning a second culture which actually means that learners are supposed to reshape their thinking to some extent (Brown, 2007, p. 194; Ji \& Yap, 2016; Vygotsky, 1962; Lakoff, 2004; Whorf, 1956; Wardhough, 1976; Piaget, 1954). 
AJESI - Anadolu Journal of Educational Sciences International, 2020; 10(1): 583-628

DOI: 10.18039/ajesi.682060

In that vein, second language teaching materials such as videos, social media, computer software, textbooks, etc. are considered to be crucial sources of input in such countries that target language is not spoken in daily life. In that vein, along with being a reference tool (Cunningsworth, 1995; Dubin \& Olshtain, 1986, O’Neil, 1982; Sheldon, 1988; Tok, 2010), it is argued that textbooks are a major source of exposure the target language for ELT students (Richards, 2010) and the cornerstone of language teaching (Hutchinson, 1987; Najafi Sarem et al., 2013). In other words, textbooks are indicated not simply tools language teachers teach in courses; instead, they embody aims, values, and methods of specific teaching or learning environment. Allwright (1981) also underlines the essential interaction of textbooks with teachers and learners for an effective learning environment. In the last few years, textbooks are considered to serve to socialize the readers into a particular ideology and worldview (Shardakova \& Pavlenko, 2004) as well as seen as cultural representations (Mohammadi \& Abdi, 2014). Similarly, the importance and meaning attached to the textbooks are quite high, especially in the Turkish education system, which is based on a central approach.

The textbooks which are the crucial source for increasing the applicability of a curriculum are the kinds of books that increase the possibility of gaining experiences to learners in learning a language. Curriculum actually plays an intermediary role between students, teachers, and parents; that's why, they are regarded to be a variable that increases the applicability of a curriculum (Litz, 2005; Mohammadi \& Abdi, 2014). With the innovations in curriculum development and teaching development, the focus is shifted to professional knowledge and skills. In the light of those innovations, the courses have been revised to encourage students to improve their skills in learning and research to improve students' understandings in different disciplines (Dole, 2017; Leat, 1999; Smith, 2010; Tam, 2017). The ultimate goal actually enables students to enhance their thinking and problem-solving skills in a creative way, and eventually to create a culture of thinking (Noor, 2019). In this regard, course 
AJESI - Anadolu Journal of Educational Sciences International, 2020; 10(1): 583-628

DOI: 10.18039/ajesi.682060

objectives, textbooks, and assessment tools in the English curriculum have been reconstructed accordingly.

Considering the basic components, learning objectives, context, and activities of the textbooks, textbook writers and teachers are needed to prepare the materials to construct a culture of thinking along with the language skills. Thus, textbooks which are the most frequently used and easily available materials are crucial to have such functions, as well as the context and activities in textbooks should have the focus on constructing a culture for thinking. Along with the textbook's required functions regarding culture of thinking, in the age of 14-15 year, the $8^{\text {th }}$ grade students also have the capability of think in an abstract manner through combining ideas (Inhelder \& Piaget, 1958, p. 277; Piaget, 1972) They have improved logical and systematic thinking, have the capability of deductive reasoning, and construct hypothetical ideas to explain various concepts (Inhelder \& Piaget, 1958). In that regard, this study seeks to examine $8^{\text {th }}$ grade English language teaching textbooks within the context of the culture for thinking.

As mentioned, this study aims at analyzing English language teaching textbooks regarding the culture of thinking. When the literature is reviewed, any study in aims at improving or evaluating the culture of thinking in second language teaching could not be found both in abroad and Turkey. In Turkey, few studies were conducted to analyze textbooks regarding improving thinking skills (Demir, 2008). The studies to teaching thinking skills and in second language teaching can be said to be in a few numbers while there are certain studies conducted to analyze textbooks in regard to the teaching thinking process and teaching (Assaly \& Smadi, 2015; Li, 2016; Hei, 2017). Still, those studies have more focus on teaching certain skills such as cognitive awareness, critical thinking, higher-order thinking skills, transfer, problem-solving skills etc. (Henderson \& Wang, 2014; Raoofi, Chan, Mukundan, \& Rashid, 
AJESI - Anadolu Journal of Educational Sciences International, 2020; 10(1): 583-628

DOI: 10.18039/ajesi.682060

2014; Apen, 2016; Li, 2016; Teng, 2016; Setyarini, Muslim, Rukmini, Yuliasri, \& Mujianto, 2018).

In that vein, this study can be regarded to contribute to the literature in improving the English language teaching curriculum, enriching ELT textbooks regarding thinking process and skills, and drawing on attention to the gap in the literature. Moonlight ( $8^{\text {th }}$ grade)'s students' book and workbook which were distributed by the Ministry of National Education and taught in state schools were taken as a basis for the study which analyzes how ELT textbooks contribute to the culture of thinking. This study seeks to examine English Language Teaching (ELT) Moonlight 8th grade students' book and workbook within the context of the culture for thinking. In that regard, the following research questions had been attempted to be answered:

1. What are the activity types in the Moonlight 8th grade students' book and workbook?

2. What are the cognitive levels of the activities in the Moonlight 8 th grade students' book and workbook?

3. How do the activities in the Moonlight 8th grade students' book and workbook contribute to the culture of thinking?

4. How do the activities in the Moonlight 8th grade students' book and workbook violate the culture of thinking?

\section{Methodology}

For this purpose, the study was carried out utilizing document analysis technique in the framework of qualitative research designs. Document analysis includes the examination of written, audio-visual and statistical materials containing information on fact or facts intended to be investigated (Yıldırım \& Şimşek, 2011, p. 187). The document examined for the purpose of the study presented in the following headline. 
AJESI - Anadolu Journal of Educational Sciences International, 2020; 10(1): 583-628

DOI: 10.18039/ajesi.682060

\section{Scope of Research or Research Documents}

The document forming the data of the research is the Middle School Moonlight English Course 8, prepared for the eighth grade. It was selected on the basis of their accessibility and widely use in state secondary schools. It was written by Esra Kandilci and published by Tutku Publishing. The students' book contains 113 pages and 271 activities. It also includes 10 units and each unit starts with the vocabulary activities and continues with reading, listening, speaking, writing, fun page, and self-check sections. On the other hand, the workbook includes 100 activities and 64 pages. In addition, the required ethical permissions have been taken before data analysis.

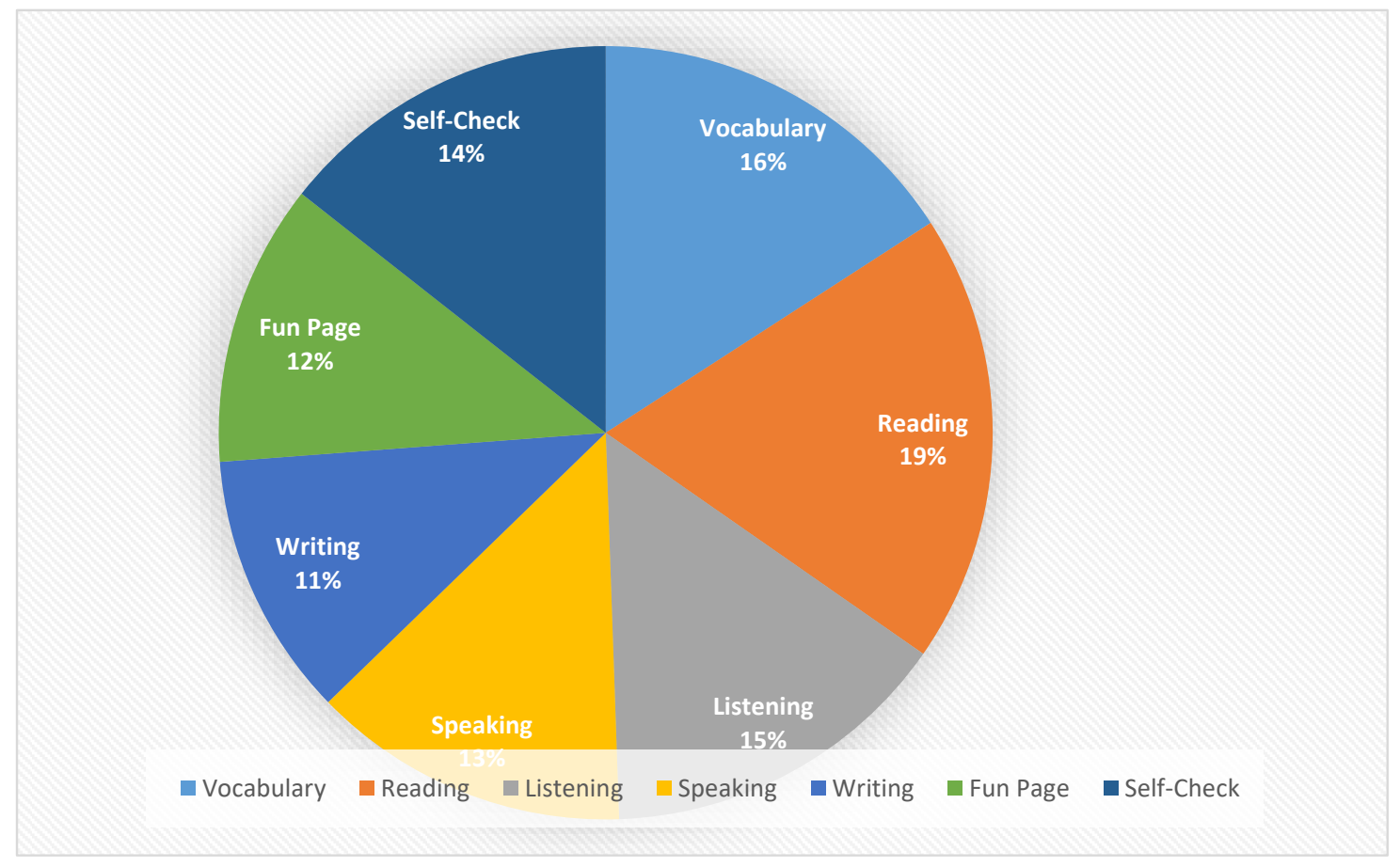

Figure 1. Frequency of the activities in the textbook in regards to language skills

\section{Data Collection and Analysis}

Descriptive analysis was utilized in data analysis (Yıldırım \& Şimşek, 2013). The framework of the culture of thinking (Tishman, Perkins, \& Jay, 1995) was taken as a basis for data analysis. In line with this framework; 
AJESI - Anadolu Journal of Educational Sciences International, 2020; 10(1): 583-628

DOI: 10.18039/ajesi.682060

- The activities in the target textbooks were reviewed regarding their cognitive levels, their contribution to the culture of thinking, and how they violate the culture of thinking.

- In examining the activities regarding to their contribution to culture of thinking, the language of thinking, the mental management, strategic spirit, and transfer which were the sub-dimensions of the culture of thinking were taken into account.

- A coding framework has been established.

- The textbook was analyzed separately by two researchers and reviewed the conformity with the coding framework.

- Two researchers evaluated the textbook separately according to this coding framework and determined which concepts were related to the activities.

- Consistency of coding was also taken attention and the incompatible codes were discussed.

- Tabulation and samples were formed and emerging codes and themes were made a literature-supported discussion.

Ethics committee approval was received for this research from Hatay Mustafa Kemal University on 08.08.2019 with the number 05 .

In order to ensure the reliability and validity of the study, the required approval by the research ethics committee was granted as a first step. After the approval, the process of data analysis was started. In that line, data were coded on the basis of the target framework, and the support was taken from experts and researchers and direct quotation were provided in the discussion of the data. It was also tried to present examples from the target textbooks in presenting findings. In addition, inter-coder reliability was calculated in regards to the formula of Miles and Huberman (1994). The result revealed that the number of disagreements in the activity type was 53 while the number of disagreements in activity levels was 6 . The inter-coder reliability was calculated as $80 \%$ for the activity type and the inter-coder reliability was 
AJESI - Anadolu Journal of Educational Sciences International, 2020; 10(1): 583-628

DOI: 10.18039/ajesi.682060

calculated as $75 \%$ for activity level. The disagreements of activity type and activity level were discussed final decision was reached for each disagreement.

\section{Findings}

This chapter presents the findings of activity types in the students' book and workbook and cognitive levels of the activities. Finally, the chapter presents to what extent and how students' book and workbook support culture of thinking. In order to systematize the presentation of the findings, the titles of the findings are listed and presented under the following headings.

Table 1

Themes in regard to Activity Types and Their Cognitive Levels

\begin{tabular}{|c|c|c|c|c|}
\hline Theme & Cognitive Level & Activity Type & SB & WB \\
\hline \multirow{6}{*}{ Retrieval } & \multirow{6}{*}{$\begin{array}{l}\text { Recognize } \\
\text { Recall }\end{array}$} & Listen and Repeat & 3 & 0 \\
\hline & & Labeling /Listing & 8 & 2 \\
\hline & & Matching & 37 & 17 \\
\hline & & True/false & 14 & 13 \\
\hline & & Fill in the blanks & 45 & 20 \\
\hline & & Underlying & 0 & 2 \\
\hline \multirow{4}{*}{$\begin{array}{c}\text { Comprehension and } \\
\text { Use }\end{array}$} & \multirow{4}{*}{$\begin{array}{c}\text { Infer } \\
\text { Compare } \\
\text { Describe } \\
\text { Execute }\end{array}$} & Answer accordingly & 43 & 20 \\
\hline & & Puzzle & 0 & 3 \\
\hline & & Making diagram & 2 & 0 \\
\hline & & Making sentence structure & 12 & 4 \\
\hline \multirow{8}{*}{$\begin{array}{l}\text { Analysis and } \\
\text { Evaluation }\end{array}$} & \multirow{8}{*}{$\begin{array}{l}\text { Analyze } \\
\text { Evaluate }\end{array}$} & Decide & 10 & 5 \\
\hline & & Ordering & 4 & 8 \\
\hline & & Discussion & 7 & 0 \\
\hline & & Interview/Questionnaire/Checklist & 4 & 0 \\
\hline & & Problem Solving & 4 & 1 \\
\hline & & Peer/Self-evaluation & 12 & 1 \\
\hline & & Error correction & 5 & 0 \\
\hline & & Elaborating questions & 8 & 1 \\
\hline \multirow{5}{*}{ Utilization } & \multirow{5}{*}{$\begin{array}{l}\text { Create } \\
\text { Integrate }\end{array}$} & Video recording & 1 & 0 \\
\hline & & Planning activity/trip & 2 & 0 \\
\hline & & Brochure/Poster/ Presentation preparation & 8 & 0 \\
\hline & & Role-play/Pandomim & 7 & 0 \\
\hline & & Free writing & 27 & 7 \\
\hline
\end{tabular}

Table 1 represents activity types in the students' book (SB) and workbook (WB), and themes and codes in regard to the cognitive level of activity types. Table 1 states that activities 
AJESI - Anadolu Journal of Educational Sciences International, 2020; 10(1): 583-628

DOI: 10.18039/ajesi.682060

in the textbooks were mostly in the level of retrieval $(f: 107)$ and comprehension $(f: 54)$. The textbooks also included activity levels of analysis and evaluation (f: 54) and utilization ( $f: 45)$. Therefore, it could be stated that the target ELT textbooks mostly encouraged students' lowerorder thinking skills.

Figure 2 can be presented as an example of the activities whose cognitive levels were retrieval. The activity in this figure asked students determine whether the sentences listed were true statements or false statements (see: Figure 2). By asking students to determine true and false statements, students were asked to recall and recognize some common courtesy rules in the situation of mobile phone uses.

5 Mark the sentences $T$ (true) or $\mathbf{F}$ (false).

$T$ 1. Most teenagers use mobile phones to communicate with their friends.

2. Using a mobile phone in the cinema is rude.

3. You should never make calls in public places, like the cinema or theatre.

4. It doesn't matter how many times your mobile rings.

5. When you use a mobile, you need to speak loudly.

Figure 2. Reading, unit 4, activity 5

Figure 3 can be presented as an example of the activities whose cognitive levels were comprehension and use. The activity in this figure asked students research the natural disaster they had selected at internet and organize the information though making diagrams after the search at net. Then, students were asked to present it in class (see: Figure 3). In this activity, students were encouraged to make some research to be able to first describe the natural disaster they had selected and to be able to describe the causes and effects of the natural disaster. Then, students were encouraged to utilize the information they had searched to figure out how they could survive before, during, and after the natural disaster by making a diagram. 
AJESI - Anadolu Journal of Educational Sciences International, 2020; 10(1): 583-628

DOI: 10.18039/ajesi.682060

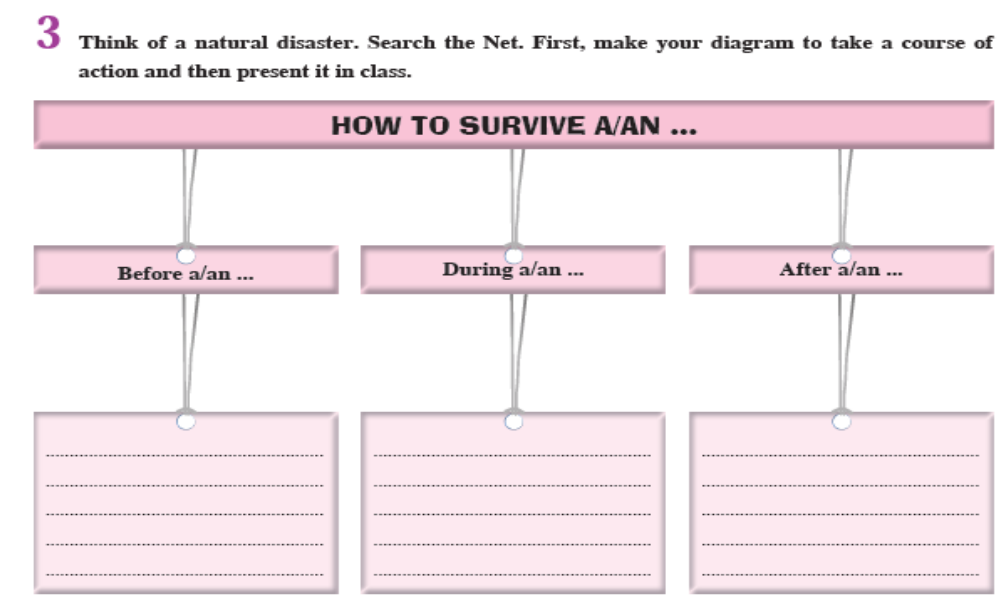

Figure 3. Reading, unit 10, activity 3

Figure 4 can be presented as an example of the activities whose cognitive levels were analysis and evaluation. The activity in this figure asked students to check and assess their peers' writings through a checklist (see: Figure 4). In this activity, students were encouraged to analyze their peers' writings and then evaluate the writings in regard to given criteria. In analyzing the writings, students were encouraged to look for and decide the strengths and weaknesses of the writings. In addition, presenting a checklist helps and directs students to what they could looked for in evaluating writings.

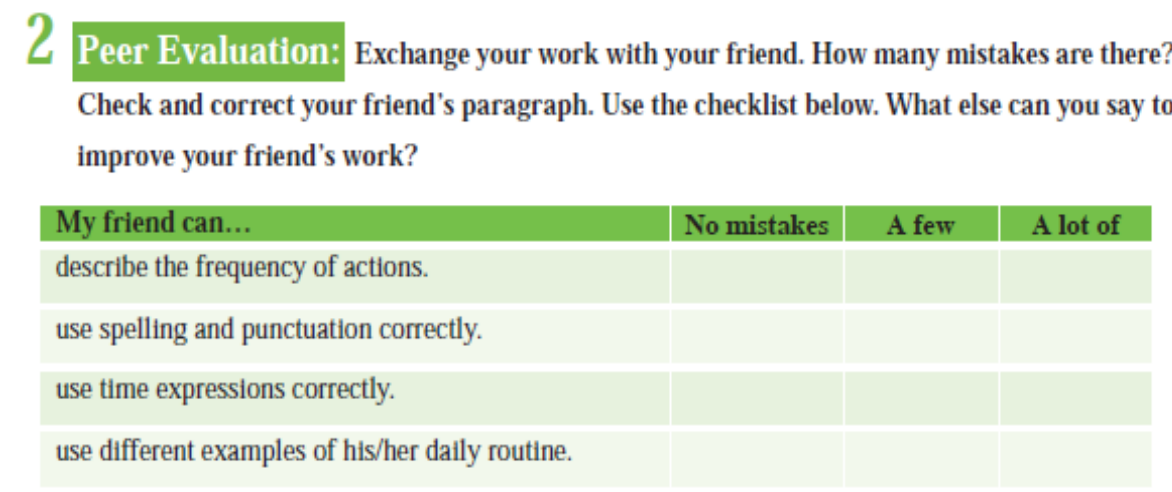

Figure 4. Writing activity, unit 2, activity 2

Figure 5 can be presented as an example of the activities whose cognitive levels were utilization. The activity in this figure is about a brochure, an advertisement or a postcard design about their favorite tourist attractions. Students were encouraged to determine their favorite 
AJESI - Anadolu Journal of Educational Sciences International, 2020; 10(1): 583-628 DOI: 10.18039/ajesi.682060

tourist attractions and search them for presentation. Then, they were asked to present their favorite tourist attractions in a brochure, an advertisement or a postcard. In this activity, students were supposed to use the information they had searched and present them in an appropriate language structures to a brochure, an advertisement or a postcard for the purpose of constructing a brochure, an advertisement or a postcard.

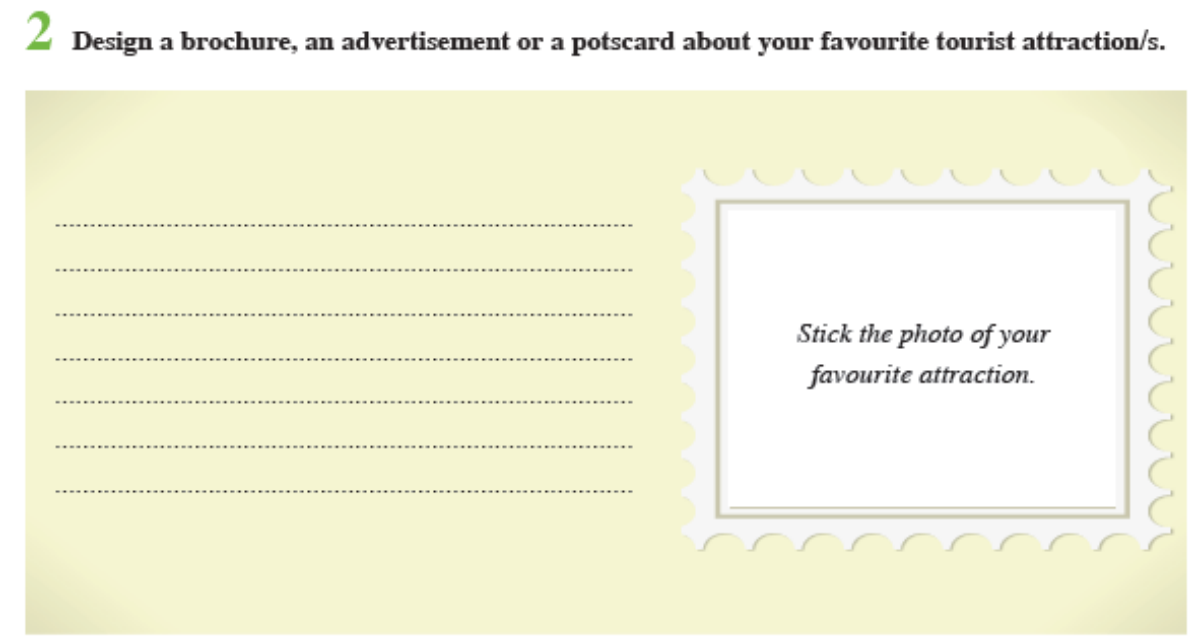

Figure 5. Writing activity, unit 7, activity 2

Table 2

The Findings of The Culture of Thinking in The Textbooks

\begin{tabular}{ll}
\hline Theme & Sub-category \\
\hline Promoting Culture of Thinking & Language of Thinking \\
& The Mental Management \\
& The Strategic Spirit \\
& Transfer \\
\hline Violating Culture of Thinking & - \\
\hline
\end{tabular}

Table 2 presents sub-categories of themes in regard to the culture of thinking of activities in the students' books and workbook. In this vein, Table 2 indicates that two main categories were shaped: Promoting the culture of thinking and violating the culture of thinking. The language of thinking, mental management, strategic spirit, and transfer were identified as sub- 
AJESI - Anadolu Journal of Educational Sciences International, 2020; 10(1): 583-628

DOI: 10.18039/ajesi.682060

categories of the theme 'promoting the culture of thinking'. Various sub-categories of the theme

'violating culture of thinking' were also determined.

\section{The Findings of Language of Thinking}

In this theme, activities were evaluated in terms of frequency of vocabulary items that lead students to think and cognitive processes. The findings in regard to how the textbooks support the development of the language of thinking were presented in Table 3.

Table 3

The Findings in regard to the Language of Thinking

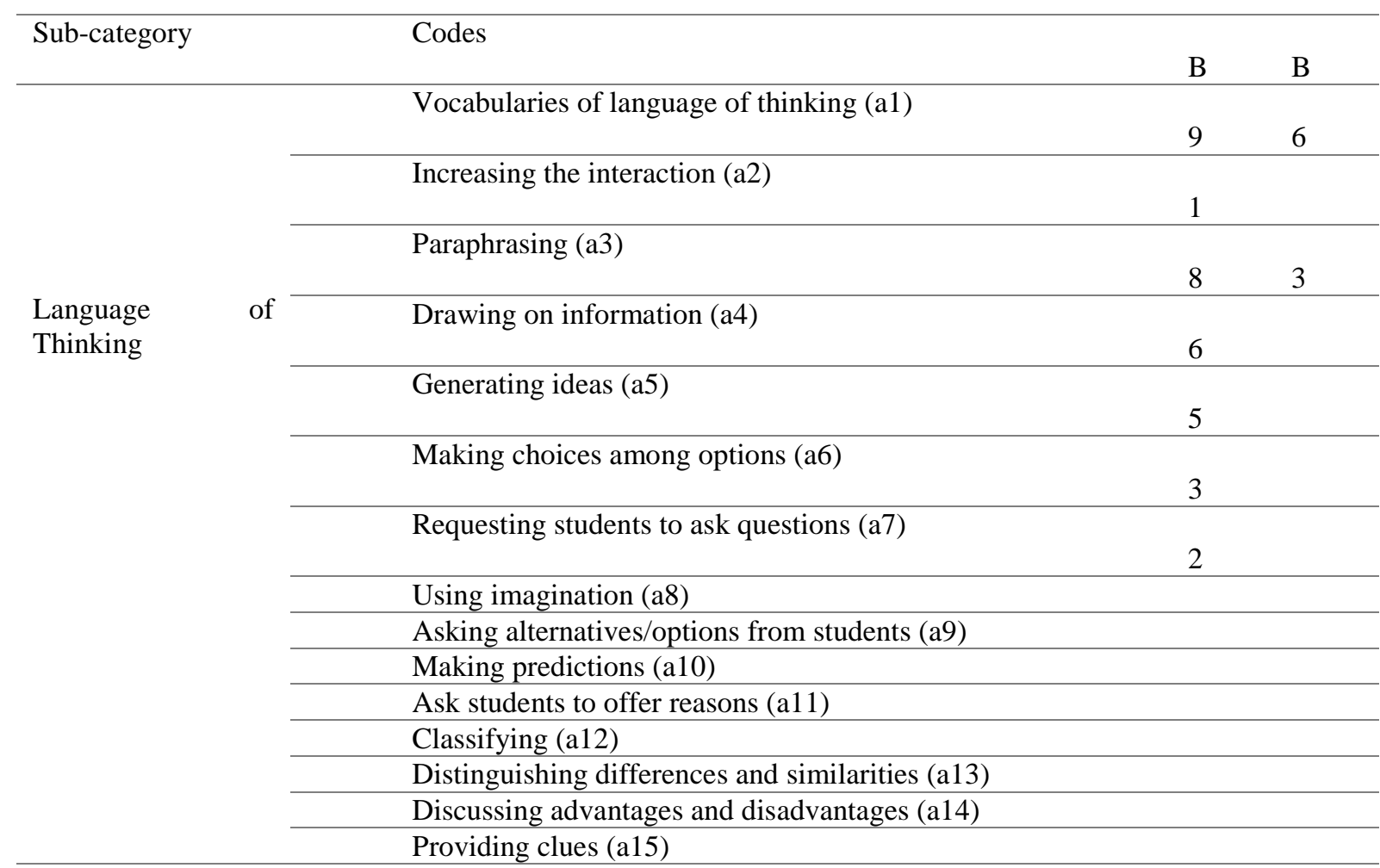

Table 3 states that the textbooks mostly utilized such language of thinking vocabularies, and certain activities to increase the interaction in the class as well as the textbooks included activities for paraphrasing, drawing on information from the context, and generating ideas in a certain number. In addition, Table 3 also included relatively fewer activities to encourage 
AJESI - Anadolu Journal of Educational Sciences International, 2020; 10(1): 583-628 DOI: 10.18039/ajesi.682060

students to making predictions, offering reasons, classifying, and distinguishing. Therefore, it could be highlighted that the target textbooks encouraged students to develop their thinking skills through vocabularies of language of thinking. Besides, the textbooks had an attempt to create a dynamic cultural environment through encouraging students to be interact, and through providing opportunities for students' thinking to improve and use language of thinking.

3 Who's your best friend? What makes him/her special? Share your ideas with your classmates.

Esma is my best friend. I can always count on her. She never tells my secrets to anyone, so I always trust her. She also backs me up, and I always support her. I get on well with her.

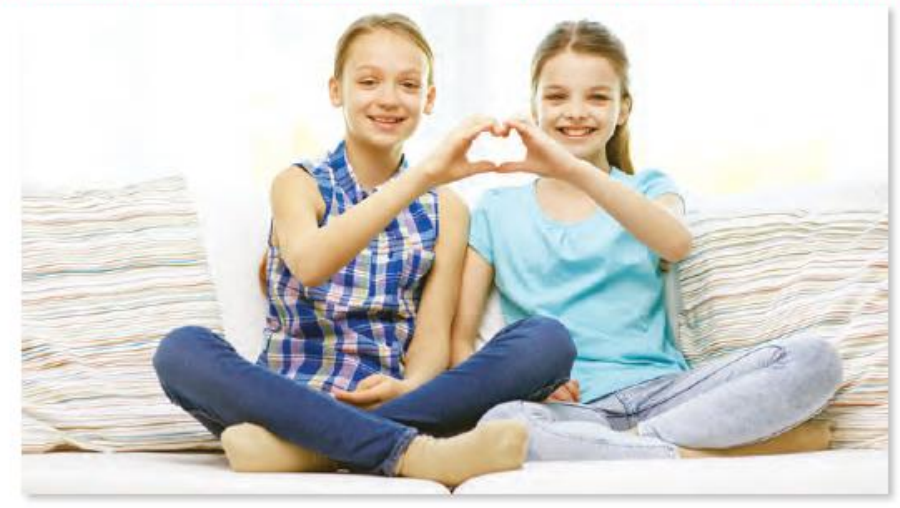

Figure 6. Vocabulary activity, unit 1 , activity 3

\section{Guess the dish in the photo. Share your ideas.}

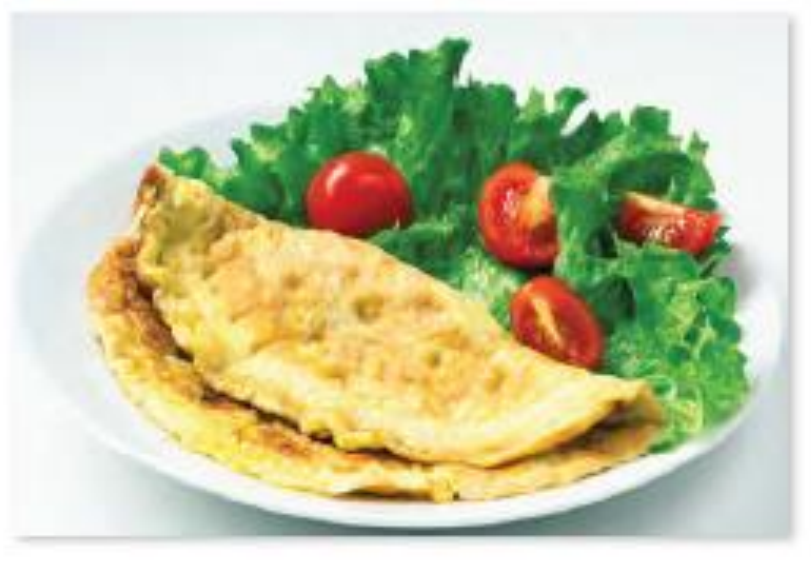

Figure 7. Listening activity, unit 3, activity 3

\section{Imagine you are on holiday. Write a postcard to your English pen-friend about your adventures.}

Think: Where are you? What activities have you done? How do you like it?

Figure 8. Reading activity, unit 6 , activity 5 
AJESI - Anadolu Journal of Educational Sciences International, 2020; 10(1): 583-628

DOI: 10.18039/ajesi.682060

Figure 1 can be shown as an example of the code 'increasing interaction' in the context of the theme 'language of thinking'. The third activity in the vocabulary part of the 'Friends' unit asked students to share their ideas with their classmates through open-ended questions (see: Figure 1). The first activity in the Listening part of 'Cooking' unit asked students to guess the dish displayed in the photo and share their guesses with their classmates (see: Figure 2). The fifth activity in the Reading part of 'Adventures' unit asked students to imagine themselves on holiday (see: Figure 3). Utilizing the vocabulary items 'share your ideas, guess, image' in those activities plays a crucial role in encouraging students to think in the second language and enriching their vocabulary knowledge in regard to the language of thinking. In addition, Figure 1 is regarded as an effective activity in increasing the interaction (f: 51) between students.

Table 4

Vocabularies of Language of Thinking in The Textbooks

\begin{tabular}{|c|c|c|c|c|c|c|c|c|}
\hline Words & $\mathbf{f}(\mathbf{D})$ & $\mathbf{f}(C ̧)$ & Words & $\mathbf{f}(\mathbf{D})$ & $\mathbf{f}(C ̧)$ & Words & $\mathbf{f}(\mathbf{D})$ & $\mathbf{f}(\mathbf{C})$ \\
\hline Think & 74 & 18 & Plan/Planning & 9 & 7 & Clear & 4 & 2 \\
\hline Check & 39 & 1 & Scientist & 8 & 1 & Research & 4 & 1 \\
\hline Answer & 37 & 15 & Possible & 8 & 3 & Mistakes & 3 & - \\
\hline Correct/correctly & 31 & 27 & Believe & 7 & 4 & Solution & 3 & - \\
\hline Problem & 29 & 15 & Mind & 7 & 4 & Alternative & 2 & - \\
\hline Question & 24 & 14 & Explain & 7 & 3 & Improve & 2 & 1 \\
\hline Understand & 22 & - & Learn & 7 & 13 & Tip & 2 & - \\
\hline Project & 22 & - & Experiment & 7 & 3 & Fact & 2 & - \\
\hline Mean/Meanings & 21 & 5 & Find out & 6 & 1 & Remember & 2 & - \\
\hline Know & 20 & 13 & Compare /Comparing & 6 & - & Agree & 1 & - \\
\hline Information & 19 & 6 & Cause & 6 & 1 & Clue & 1 & - \\
\hline Look at & 19 & 8 & Guess & 6 & 2 & Difference & 1 & 1 \\
\hline Ideas & 16 & 2 & Similar & 5 & 2 & Conduct & 1 & - \\
\hline Interesting & 16 & 1 & Act out & 5 & - & $\begin{array}{l}\text { Peer } \\
\text { Evaluation }\end{array}$ & 1 & - \\
\hline Different & 15 & 5 & Discuss & 5 & 2 & Imaginary & 1 & - \\
\hline Science & 13 & 7 & Result & 5 & 1 & Choice & 1 & - \\
\hline Ask & 12 & 2 & $\begin{array}{l}\text { Main idea/ point/ } \\
\text { content/ ways }\end{array}$ & 5 & 2 & Evaluation & 1 & - \\
\hline Reason & 12 & 3 & Careful & 4 & 3 & Suggest & 1 & - \\
\hline Change/exchange & 11 & 2 & Decide & 4 & 1 & Synthesis & 1 & - \\
\hline Opinion & 11 & 1 & Discover & 4 & 4 & Unknown & 1 & - \\
\hline Imagine & 10 & 3 & Search & 4 & 3 & Prediction & 1 & - \\
\hline Choose & 10 & 9 & Option & 4 & 4 & & & \\
\hline
\end{tabular}


AJESI - Anadolu Journal of Educational Sciences International, 2020; 10(1): 583-628

DOI: 10.18039/ajesi.682060

Table 4 and Table 5 present that 69 vocabulary items were utilized to support the language of thinking in the students' book and the workbook included 46 vocabulary items of the language of thinking. The most frequently used vocabulary items were 'think', 'check', 'answer'. However, the vocabulary 'agree', 'clue', 'different', 'imaginary', 'choice', 'evaluation', and 'prediction' which are crucial vocabularies for the language of thinking were utilized once in students' book and were not used workbook at all.

Table 5

The Distribution of Vocabulary of The Language of Thinking in regard to The Units

\begin{tabular}{|c|c|c|c|c|c|c|c|c|c|c|c|}
\hline & $\begin{array}{c}\text { Unit } \\
1\end{array}$ & $\begin{array}{c}\text { Unit } \\
2\end{array}$ & $\begin{array}{c}\text { Unit } \\
\mathbf{3}\end{array}$ & $\begin{array}{c}\text { Unit } \\
4\end{array}$ & $\begin{array}{c}\text { Unit } \\
5\end{array}$ & $\begin{array}{c}\text { Unit } \\
6\end{array}$ & $\begin{array}{c}\text { Unit } \\
7\end{array}$ & $\begin{array}{c}\text { Unit } \\
8\end{array}$ & $\begin{array}{c}\text { Unit } \\
9\end{array}$ & $\begin{array}{c}\text { Unit } \\
10\end{array}$ & Total \\
\hline Think & $3(-)$ & $9(2)$ & $4(1)$ & $5(3)$ & $\begin{array}{l}12 \\
(6)\end{array}$ & $\begin{array}{l}20 \\
(3)\end{array}$ & $1(-)$ & $\begin{array}{l}12 \\
(3)\end{array}$ & $2(0)$ & $6(0)$ & $74(18)$ \\
\hline Check & $4(-)$ & $3(-)$ & $3(-)$ & $6(-)$ & $3(-)$ & $5(-)$ & $3(-)$ & $3(1)$ & $5(-)$ & $4(-)$ & $39(1)$ \\
\hline Answer & $3(1)$ & $2(-)$ & $3(-)$ & $4(1)$ & $8(-)$ & $3(1)$ & $2(2)$ & $6(3)$ & $3(1)$ & $3(1)$ & 37 (10) \\
\hline $\begin{array}{l}\text { Correct/ } \\
\text { correctly }\end{array}$ & $4(3)$ & $5(4)$ & $4(1)$ & $0(2)$ & $1(2)$ & $1(3)$ & $4(2)$ & $4(2)$ & $6(5)$ & $2(3)$ & $31(27)$ \\
\hline Problem & $4(-)$ & $0(-)$ & $0(1)$ & $1(-)$ & $5(6)$ & $0(-)$ & $0(1)$ & $7(3)$ & $5(3)$ & $7(1)$ & $29(15)$ \\
\hline Question & $3(2)$ & $2(2)$ & $1(3)$ & $1(1)$ & $8(-)$ & $1(1)$ & $0(1)$ & $4(2)$ & $1(1)$ & $2(1)$ & $24(14)$ \\
\hline $\begin{array}{l}\text { Understa } \\
\text { nd }\end{array}$ & $1(-)$ & $1(-)$ & $3(-)$ & $2(-)$ & $3(-)$ & $1(-)$ & $1(-)$ & $2(-)$ & $4(-)$ & $4(-)$ & $22(-)$ \\
\hline Project & $2(-)$ & $2(-)$ & $2(-)$ & $2(-)$ & $3(-)$ & $2(-)$ & $2(-)$ & $2(-)$ & $3(-)$ & $2(-)$ & $22(-)$ \\
\hline Know & $4(1)$ & $1(1)$ & $2(2)$ & $1(1)$ & $1(-)$ & $0(-)$ & $2(3)$ & $3(1)$ & $5(4)$ & $1(-)$ & $20(13)$ \\
\hline
\end{tabular}

Table 5 indicates that when the most frequent 9 vocabulary items of the language of thinking were examined in regard to units, the fifth unit 'The Internet' and the seventh unit 'Tourism' included the highest number of the vocabulary of the language of thinking.

\section{The Findings of Mental Management}

Activities in the textbook were analyzed regarding students' awareness of their learning process, having control of their learning process, monitoring their learning process and regulating their learning process under the theme 'mental management'. Table 6 presents the findings in regard to how activities in the textbooks support mental management. 
AJESI - Anadolu Journal of Educational Sciences International, 2020; 10(1): 583-628

DOI: 10.18039/ajesi.682060

Table 6

The Findings Regarding Mental Management

\begin{tabular}{clcc}
\hline Sub-category & Codes & SB & WB \\
\hline & Checking Progress (b1) & 26 & 1 \\
\cline { 2 - 3 } & Raising awareness to phrases or structure (b2) & 13 & 8 \\
\cline { 2 - 3 } The Mental & Asking students to research (b3) & 5 & - \\
\cline { 2 - 3 } Management & Examining and learning from mistakes (b4) & 8 & 6 \\
\cline { 2 - 3 } & Raising awareness to problem solving process (b5) & 3 & - \\
\cline { 2 - 3 } & Making suggestions (b6) & 5 & - \\
\cline { 2 - 3 } & Underlying correct words/ phrases (b8) & 2 & 7 \\
\cline { 2 - 3 } & Creating criteria (b9) & 2 & - \\
\cline { 2 - 3 } & Giving advise(b10) & 2 & - \\
\cline { 2 - 3 } & Recall past experiences and perceptions (b11) & 1 & - \\
\cline { 2 - 3 } & Considering what may be missing (b12) & 3 \\
\hline
\end{tabular}

Looking at Table 4, the textbooks were indicated to include a certain number of activities to encourage students to check their own processes, raise awareness to phrases or structure, and examine and learn from mistakes. However, the textbooks included relatively fewer activities to create criteria for students, recall past experiences perceptions, make suggestions, and consider what may be missing. Therefore, it could be pinned down that the target textbooks helped organize students' thinking processes through encouraging them to raising their metacognition skills and taking control of their thinking.

Peer Evaluation: Exchange your work with your friend. How many mistakes are there? Check and correct your friend's paragraph. Use the checklist below. What else can you say to improve your friend's work?

\begin{tabular}{|c|c|c|c|}
\hline My friend can... & No mistakes & A few & A lot of \\
\hline describe the frequency of actions. & & & \\
\hline use spelling and punctuation correctly. & & & \\
\hline use time expressions correctly. & & & \\
\hline use different examples of his/her daily routine. & & & \\
\hline
\end{tabular}

Figure 9. Writing activity, unit 2, activity 2 
AJESI - Anadolu Journal of Educational Sciences International, 2020; 10(1): 583-628

DOI: 10.18039/ajesi.682060

3 What's a typical Monday like for you? Answer these questions. Then write a short paragraph.
1. What time do you get up?
6. When does your school finish?
2. What do you do after you get up?
7. Where do you have lunch?
3. How do you feel?
8. What are your after-school activities?
4. How do you go to school?
9. What do you do in the evening?
5. What time do your lessons start?
10. What time do you go to bed?

Figure 10. Writing activity, unit 2, activity 3

\section{Express your preference for different tourist attractions and give your reasons.}

I'd rather visit historic sites because to me, they are usually more interesting. To me, historical architecture is more beautiful than modem buildings.

Figure 11. Speaking activity, unit 7, activity 3

The second activity in the 'Teen Life' unit (see: Figure 4) is considered to guide students to manage their minds in terms of making error correction on their peers' works and evaluating their peers through the checklist. In addition, this activity is efficient in being a model for creating criteria in evaluation. The third activity in Figure 5 asked students to ten open-ended questions to shape their answers and write a short paragraph by combining their answers. This activity can be regarded as a crucial activity in raising awareness of improving writing skills. Another sample activity in that theme in regard to mental management is presented in Figure 6 in which the activity encourages students to deepen thinking by asking students to give reasons. This activity also offers a guideline or model by giving sample reasons to students. 
AJESI - Anadolu Journal of Educational Sciences International, 2020; 10(1): 583-628

DOI: 10.18039/ajesi.682060

\begin{tabular}{|c|c|c|c|}
\hline \multicolumn{4}{|l|}{ Check Your Progress } \\
\hline \multicolumn{4}{|c|}{ Read the sentences. Think about your progress and tick $(\checkmark)$ the boxes. } \\
\hline & Excellent & OK & Difficult \\
\hline \multicolumn{4}{|l|}{ I can understand TV news and reports about natural disasters. } \\
\hline \multicolumn{4}{|l|}{ I can understand phrases and expressions about natural disasters. } \\
\hline \multicolumn{4}{|l|}{ I can make predictions about the future of Planet Earth. } \\
\hline \multicolumn{4}{|l|}{$\begin{array}{l}\text { I can make simple suggestions about saving the Earth from } \\
\text { natural disasters. }\end{array}$} \\
\hline \multicolumn{4}{|l|}{$\begin{array}{l}\text { I can express my personal opinions about the causes of natural } \\
\text { disasters. }\end{array}$} \\
\hline \multicolumn{4}{|l|}{ I can understand the words/phrases in a text about natural events. } \\
\hline I can write predictions about the future of the planet. & & & \\
\hline
\end{tabular}

Figure 12. Self-check, unit 10

'Check your progress' in Figure 7 included at the end of each unit and asked students to check their progress. Self-evaluation plays an important role in the culture of thinking. That activity can turn into a more powerful and efficient activity in regard to the culture of thinking by identifying students' extra studies to overcome the deficiencies in the unit.

\section{The Findings of Strategic Spirit}

The theme 'strategic spirit' intended to provide students with a step-by-step way to perform the task presented in the activity, or to plan for the students to fulfill this task. The table in the following represents the findings in regard to how the activities in the textbooks support the strategic spirit.

Table 7

The Findings Regarding Strategic Spirit

\begin{tabular}{clcc}
\hline Sub-category & Codes & SB & WB \\
\hline $\begin{array}{c}\text { The Strategic } \\
\text { Spirit }\end{array}$ & The instructions related to planning (c1) & 5 & 2 \\
\cline { 2 - 4 } & Open-ended questions related to strategic spirit (c2) & 8 & 3 \\
\hline
\end{tabular}


AJESI - Anadolu Journal of Educational Sciences International, 2020; 10(1): 583-628

DOI: 10.18039/ajesi.682060

\begin{tabular}{l|cc} 
Applying learning strategies (c3) & 15 & 4 \\
\hline Applying communicative strategies (c4) & 1 & - \\
\hline Following the steps (c5) & 3 & -
\end{tabular}

Table 7 indicates that the students' book included relatively more activities to encourage students to make plans, apply learning strategies, and activities that ask open-ended questions for constructing their strategic spirits. However, the students' book offered relatively fewer activities to encourage students to apply communicative strategies, and follow the steps. On the other hand, the workbook offered such activities that promote the instructions related to planning and open-ended questions for constructing strategic spirit as well as activities that ask students to apply learning strategies. Therefore, it could be stated that the target textbooks had an attempt to be a model students and encouraged students to build and utilize thinking strategies in language learning with the aim of making the learning process more effective.

3 Work in pairs. Plan an interesting weekend activity with your friend. Follow the steps below, and act out the following dialogue to give you an idea.

1. Dial your friend, introduce yourself and greet him/her.

2. Invite him/her to do an activity together.

3. Give some information about the activity, the time, the place, the people, etc.

4. Repeat your sentences when your friend can't follow you.

5. Say your good wishes and hang up the phone.

Figure 13. Speaking activity, unit 4 , activity 3 
AJESI - Anadolu Journal of Educational Sciences International, 2020; 10(1): 583-628

DOI: 10.18039/ajesi.682060

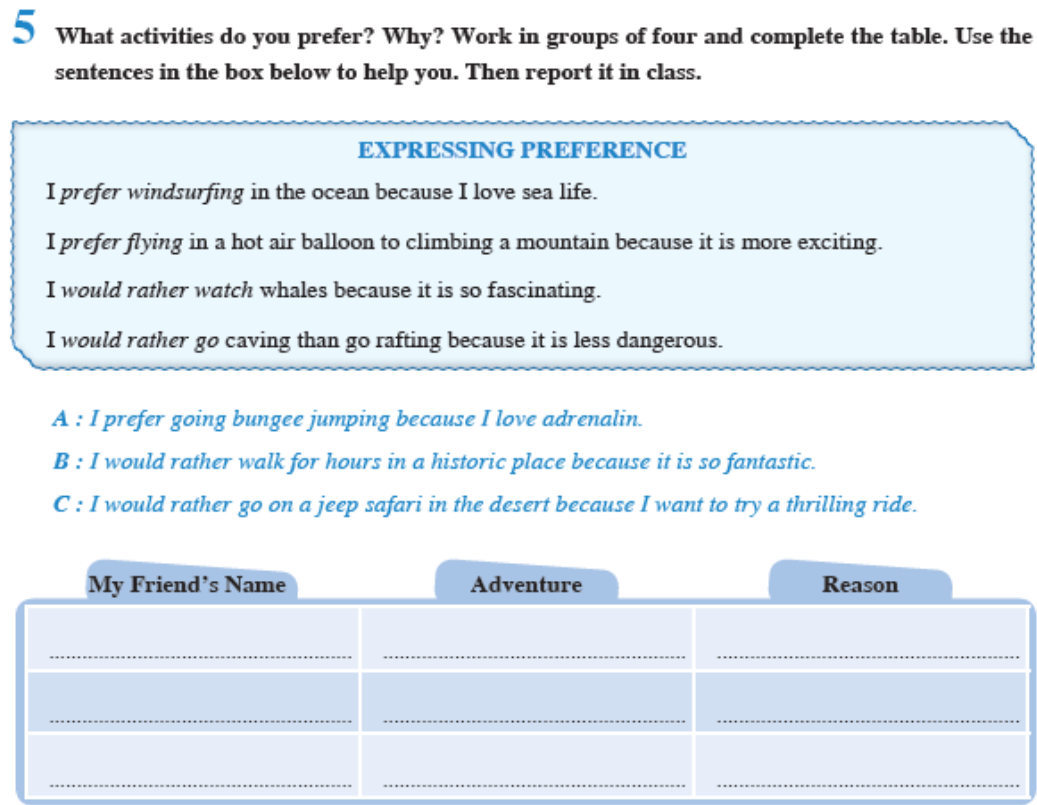

Figure 14. Vocabulary activity, unit 6 , activity 5

As for the codes 'planning' and 'following the steps', the third activity in the speaking part of 'Communication' unit asked students to plan a weekend activity. The points required to be remarked are presented in steps. Therefore, this activity was tried to be a model to students along with offering a strategy for carrying out the activity (see: Figure 8). Similarly, Figure 9 assigned students a task regarding the code 'applying learning strategies'. It was also a model for students by presenting a table for students to how to organize information.

\section{The Findings of Transfer}

The theme transfer refers to interiorizing teaching by integrating the tasks in the textbooks with their lives. Table 8 represents the findings in regard to how the activities in the textbooks support transfer.

Table 8

The Findings Regarding Transfer

\begin{tabular}{llll}
\hline Sub-category & Codes & SB & WB \\
\hline Transfer & Integrating topics with students' lives (d1) & 42 & 6 \\
\hline
\end{tabular}


AJESI - Anadolu Journal of Educational Sciences International, 2020; 10(1): 583-628

DOI: 10.18039/ajesi.682060

Table 8 presents that a certain number of activities in the textbooks asked some openended questions to students for encouraging them to integrate the target topics and subjects with their lives. Therefore, the target textbooks had an attempt to encourage students to apply their knowledge and strategies to various contexts

3 Game Think of funny rules for your house. Make sentences in teams. Each correct sentence gets 1 point. The team with the most points is the winner.

Team A S1: You must leave the rubbish in.

Team B S1: You don't have to make your bed.'

Figure 15. Fun page, unit 8 , activity 3

Work in pairs. What's the most important scientific development in your opinion? Why? Discuss with your partner.

To me, the most important scientific development is the penicillin because antibiotics are powerful drugs that kill dangerous bacteria in our bodies.

Figure 16. Speaking activity, unit 9 , activity 4

The code regarding the theme transfer was shaped by paying attention to the game in the Fun page part of 'Chores' unit which asked students to make decisions on the rules of their houses (see: Figure 10). In the similar vein, the fourth speaking activity in the 'Science' unit encourages students to make transfers by asking them to discuss the most important scientific development (see: Figure 11). Those kinds of activities are considered to be efficient in improving the culture of thinking in an authentic environment.

\section{The Findings of Violating Culture of Thinking}

Besides the findings promoting the culture of thinking, the findings regarding violating the culture of thinking were also detected. The findings regarding violating culture of thinking were presented in Table 9. 
AJESI - Anadolu Journal of Educational Sciences International, 2020; 10(1): 583-628

DOI: 10.18039/ajesi.682060

Table 9

The Findings Regarding the Violating Culture of Thinking

\begin{tabular}{lll}
\hline Codes & SB & WB \\
\hline Vague/unclear instructions (e1) & 44 & 2 \\
\hline Insufficient context (e2) & 20 & - \\
\hline Limiting the act of thinking by giving options (e3) & 18 & 8 \\
\hline Not giving detailed instructions to the planning process to activities (e4) & 16 & - \\
\hline Directly doing activities as in the example (e5) & 13 & 5 \\
\hline Not providing criteria for evaluation of the projects (e6) & 10 & - \\
\hline Direct guided to dictionary use (e7) & 3 & - \\
\hline Inappropriate context to culture $(\mathbf{e 8})$ & 2 & - \\
\hline Outdated activities $(\mathbf{e 9})$ & 1 & - \\
\hline
\end{tabular}

Table 9 explored that the students' book included a certain number of activities that had vague instructions, an insufficient context for learning, undetailed instructions, and activities that limited the act of thinking by giving options. The activities in the students' book also asked students to directly did activities as in the example and did not provide certain criteria for evaluation of the projects. Relatively fewer activities guided students to dictionary use, provide inappropriate context for culture and outdated activities. On the other hand, the workbook had a certain number of activities that had vague/unclear instructions, guided students to use dictionaries, and activities that limited the act of thinking by giving options. Therefore, it could be highlighted that even though the findings supporting the culture of thinking in regard to the language of thinking, mental management, strategic attitude, and transfer, activity types, they mostly had certain problems with constructing the culture of thinking.

1 Match the words (1-7) with the definitions (a-g). Use your dictionaries.

\begin{tabular}{|c|c|c|}
\hline 1. a buddy/mate & $\ldots \ldots$ & $\begin{array}{l}\text { a) only a few people know something } \\
\text { and they don't tell it to anybody }\end{array}$ \\
\hline 2. count on & & b) rely on \\
\hline 3. get on well & -.......... & c) a friend \\
\hline 4. laid-back & ............ & d) have a good relationship \\
\hline 5. a secret & ............. & $\begin{array}{l}\text { e) a group of teens spend the night at } \\
\text { one of the teens' house }\end{array}$ \\
\hline 6. a slumber party/pyjama party/sleepover & ........... & f) help someone \\
\hline 7. back up & ........... & g) relaxed, not worried \\
\hline
\end{tabular}

Figure 17. Vocabulary activity, unit 1 , activity 1 


\section{Read the first letter. What's Jenny's problem? Choose the correct option. \\ a) Jenny is selfish. b) Jenny's jealous of Mel's new friend. c) Jenny hasn't got any friends.}

Figure 18. Reading activity, unit 1, activity 6

\section{- PR0JECT \\ Choose a city or a place. Prepare a short travel brochure for that city/place. Use visuals. Put your project into your portfolio.}

Figure 19. Project, unit 7

The first vocabulary activity in the 'Friends' unit can be shown as an example to the findings of violating the culture go thinking. The activity may turn into a more encouraging activity to the culture of thinking through reorganizing it by asking students to infer the meanings of vocabulary items (see: Figure 12); therefore, the activity may be more efficient in terms of the themes of language of thinking, mental management, the strategic spirit, and transfer. The sixth reading activity in the same unit limited students thinking by giving them options regarding the answer (see: Figure 13). Another part of the textbook which is required to be reorganized regarding the culture of thinking is the project tasks at the end of each unit. Even though project tasks are quite essential in promoting the culture of thinking, the language of thinking, mental management, the strategic spirit, and transfer were limited by not giving step-by-step instructions to the projects and vague or unclear instructions to evaluation criteria in the project tasks (see: Figure 14). This also applies to the 10 projects listed in the book. 
AJESI - Anadolu Journal of Educational Sciences International, 2020; 10(1): 583-628

DOI: 10.18039/ajesi.682060

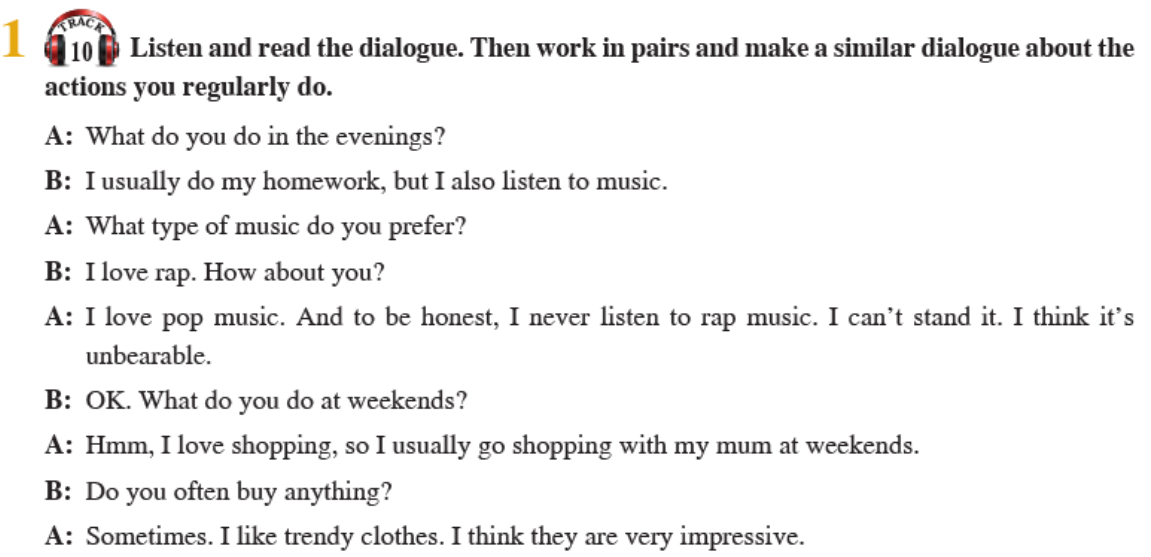

Figure 20. Speaking activity, unit 2, activity 1

Another important code that restricts thinking is the instructions for 'do the activity as in the example' or 'doing an activity similar to the given one' (see: Figure 15). Instead, the students should be briefly informed about the points they need to pay attention to while performing the task so that they can develop both mental management and strategic attitude.

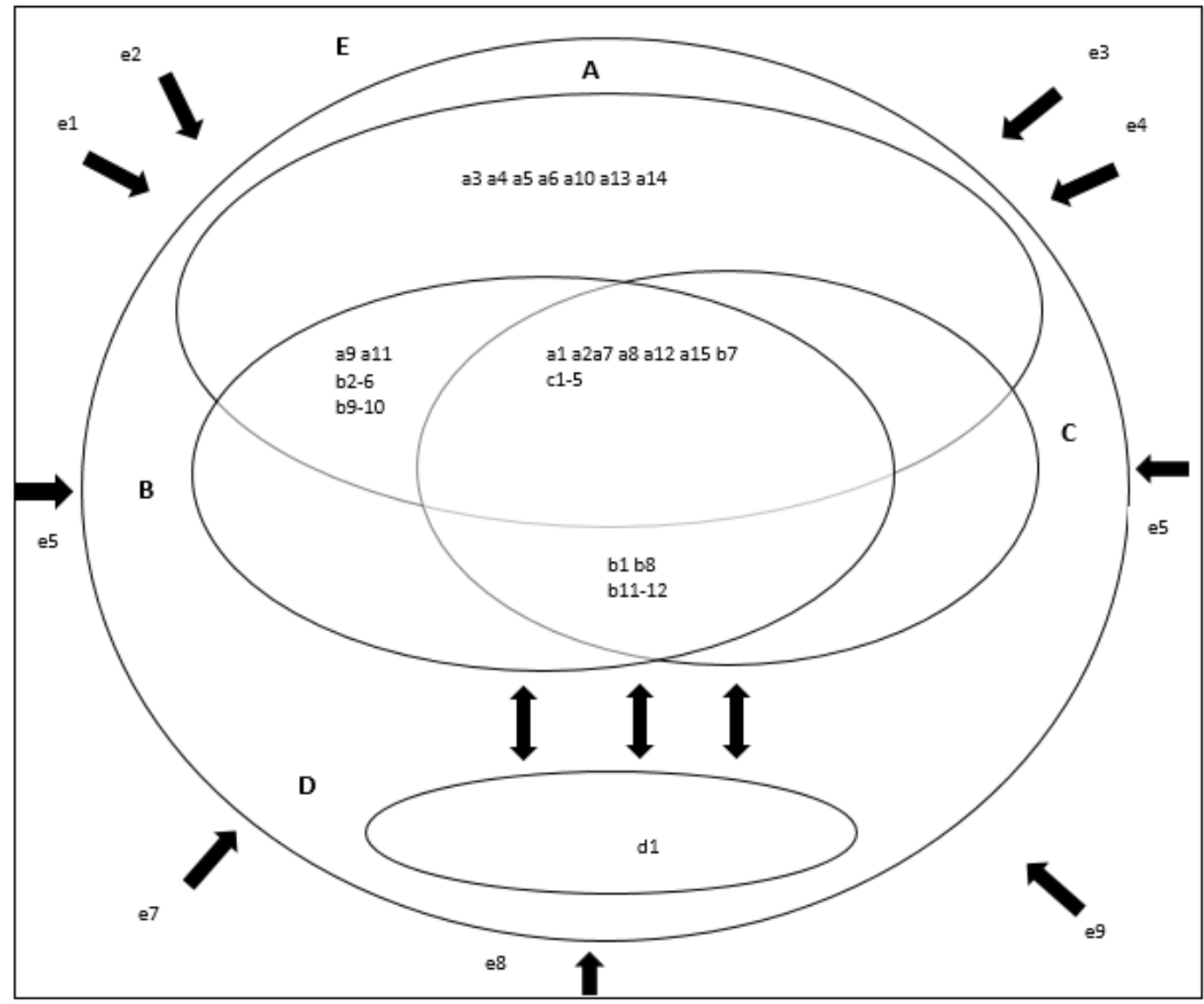

Figure 21. Summary of the findings regarding the culture of thinking in textbooks 
AJESI - Anadolu Journal of Educational Sciences International, 2020; 10(1): 583-628

DOI: 10.18039/ajesi.682060

Footnote: A=Language of Thinking, $B=$ Mental Management, $C=$ Strategic Spirit, $D=$ Transfer, E=Violating Culture of Thinking

Figure 16 which summarizes the research findings explored the tasks are promoting the culture of thinking in the textbook, as well as the findings that may have a negative effect on the development of the culture of thinking. As can be seen in Figure 16, it is noteworthy that the dimensions of the culture of thinking (the language of thinking, mental management, the strategic spirit, and transfer) cannot be completely separated from each other and there is a transition between these dimensions. Even though the target textbooks included such activities that supporting language of thinking, mental management, the strategic spirit, and transfer, they also provided vague instructions, insufficient contexts, inappropriate contexts to culture, outdated activities, etc. which could seriously threaten building culture of thinking.

\section{Results and Discussion}

The main objective of English curriculum of the secondary school is to train individuals who use English at an international level, as well as to train individuals with competences such as learning to learn and creativity (MoNE, 2018). In this vein, teachers and textbook writers are expected to create contexts and assign tasks that develop these competencies. However, English language teaching textbooks are indicated not to be at the desired level in developing thinking skills (Demir, 2008; Özmen, 2008). The target textbooks examined for the purpose of the study have been accepted as the textbooks for 5 (five) years starting from the 2017-2018 academic year with the decision of the Ministry of National Education, the Board of Education and Discipline dated 31.05.2016 and numbered 33. The students' book and workbook (Moonlight 8th grade students' book and workbook) examined in this study were also explored to be limited in developing and supporting the culture of thinking. In particular, it is important to develop and support the thinking skills of 8th-grade students who are going through the formal 
AJESI - Anadolu Journal of Educational Sciences International, 2020; 10(1): 583-628

DOI: 10.18039/ajesi.682060

operational stage. Especially in the language teaching where cognitive processes and skills are very active, it is very important to develop a culture of thinking.

The use of the vocabulary of the language of thinking in the students' book and workbook has a positive effect on constructing the culture of thinking. However, increasing the frequency of such vocabulary use as agree, clue, difference, imaginary, choice, evaluation, prediction, which is regarded as important vocabulary items in terms of the language of thinking, can positively affect the culture of thinking. In fact, the contexts of unites identified in the curriculum can be indicated to trigger thinking processes and skills. When the tasks in the book are examined, it is a remarkable positive finding that supports peer learning. Peer learning is regarded to be among the most efficient learning strategies (Levine, Glass, \& Meister, 1987) since it has great contribution to students' social, psychological and affective needs (Johnson \& Johnson, 1986; Slavin, 1990; Cohen, Kulik, \& Kulik, 1982; Rohrbeck, Ginsburg-Block, Fantuzzo, \& Miller, 2003; Sharpley \& Sharpley, 198; Griffths et al., 1995) as well as foster certain aspects of lifelong learning skills (Slavin, 1990). Therefore, it is quite essential for students to be in interaction with each other, that is, to establish dialogues, both in terms of course outcomes and thinking processes. However, when the students are encouraged to interact with each other, the language used is very crucial. In particular, textbook writers should pay attention to encouraging the act of thinking when writing such instructions. Especially when the findings of promoting the culture of thinking and the findings of violating culture of thinking are completely examined, there is a risk that negative expressions will overshadow other positive expressions.

Along with the language of thinking, certain activities have a contribution to other dimensions of culture of thinking. The activities which encourage students to raise their awareness of their learning process, to deepen their thinking, and which are a model for students in restructuring their minds had a positive effect on improving the dimension of mental 
AJESI - Anadolu Journal of Educational Sciences International, 2020; 10(1): 583-628

DOI: 10.18039/ajesi.682060

management. The activities which offered students to certain learning and communicative strategies had also contributed to constructing students' strategic spirit. In other words, those kinds of activities foster comprehension, raising awareness, inference, argumentation, monitoring, and evaluating. Regarding the results, there are outstanding findings that contribute to metacognition skills. The activities under the theme of mental management and strategic spirit could be required to improve students' higher-order thinking, problem-solving, and critical thinking skills. In addition, raising awareness students' cognitive processes through asking students to making plans about the assigned tasks and applying various learning and communicative strategies, encouraging students to monitor their comprehension and performance through such activities as paraphrasing, as well as encouraging students to check their learning processes and performances through checklists could be considered to enhance students' metacognition skills.

Metacognition refers to one's knowledge of one's cognitive processes (Flavell, 1976, p.232) and its crucial role in learning and thinking have been explored in studies in the literature (Garner \& Alexander 1989; Halpern 2003; Mayer 1998; Norris 1991). Metacognition skills are argued to be among the most essential skills which help students develop their second language skills. Instead of focusing on learning the target language, metacognition skills may be more efficient in guiding students to explore what happens in their second language learning processes and consequently improve their language skills (Anderson, 2002). A number of studies in the literature also highlight the effectiveness of metacognition skills on students' second language learning outcomes (Reid \& Hresko, 1982; Weinert \& Kluwe, 1987). Those findings revealed that metacognition skills help students compensate their possible weaknesses, therefore, they may have a facilitating effect on students' language learning skills by encouraging them to be initiators of their own learning and rely on their potential, and eventually to become autonomous learners. 
AJESI - Anadolu Journal of Educational Sciences International, 2020; 10(1): 583-628

DOI: 10.18039/ajesi.682060

Since learning depends on the student's use of learning under another condition, the dimension of transfer is among the most important evidence of learning (Perkins \& Salamon, 2012). In other words, the way to become a good thinker is through transfer (Perkins \& Ritchart, 2004). The dimension of transfer is also very essential in terms of integrating the language skills taught in the English curriculum with daily life (MoNE, 2018). In many disciplines, we face the challenge of failing to integrate learned skills into daily life (Perkins \& Salamon, 2012). In the textbook examined, it was determined that the tasks related to the integration of students with their lives were included. 48 of the 371 activities in the students' book and workbook offer the tasks which aimed at integrating students with the daily life of the students. In this context, the students' book and workbook can be stated to be utilized as a reference book for teachers. However, the quality and quantity of the activities should be highlighted to be increased in the context of transfer. Because it is essential for authentic learning that the activities in the target textbooks should be of sufficient quality and quantity to facilitate the transfer. It may also contribute to the increase of students' intrinsic motivation. In other words, transfer helps build a bridge between the English language teaching classroom and life (Perkins \& Salamon, 2012).

The analysis offers the findings supporting the culture of thinking in regard to the language of thinking, mental management, the strategic attitude, and transfer. However, almost half of the activities had certain problems with constructing the culture of thinking regarding the findings of violating the culture of thinking. In this vein, instructions and given contexts in the target textbooks can be generally considered to have a negative effect on the culture of thinking. Such instructions as 'do as in the example', 'use dictionary' as well as giving options for students to choose among them can limit improving students thinking skills. Instead of those instructions, the activities can be reconstructed in terms of utilizing such instructions and certain vocabulary of the language of thinking to support students' development of thinking and learning strategies. Also, instructions should be a model for students to organize their thinking 
AJESI - Anadolu Journal of Educational Sciences International, 2020; 10(1): 583-628

DOI: 10.18039/ajesi.682060

and learning process. However, not providing detailed instructions for their planning process or criteria for evaluation process may cause students to not successfully manage to organize their thinking processes; and consequently, they may fail to guide students to construct their culture of thinking. In addition, context is another essential component for the culture of thinking since context provides students a learning and thinking environment. However, providing insufficient context and inappropriate contexts with outdated activities can limit students' thinking and learning processes, as well as demotivate students to improve their thinking skills and to construct the culture of thinking. Therefore, those findings can be emphasized to have a risk to overshadow the findings of supporting the culture of thinking.

In addition to those findings, another effect of the findings regarding violating culture of thinking should be required to be discussed in the context of learning a foreign language. Teaching culture as a part of foreign language learning have been drawn attention in the last three decades; and consequently, students are required to get familiarity with the thinking systems of the target language, and eventually reshape their thinking skills (Brown, 2007, p. 194; Ji \& Yap, 2016; Savignon, 1972; Canale \& Swain, 1980; Tang, 1999). And the curriculum and the textbooks should be reshaped accordingly. However, the textbooks generally fail to improve students' cultural understanding of the target language and tend to bestow one-sided views of the target culture (Kramsch, 1988; Lafayette 1988). In this vein, Şimşek (2017) aimed to explore prospective teachers' preferences in regard to cultural objects in material adaptation. However, the findings revealed that only a few adopters raise their gender- and culturalawareness, and increase classroom interaction.

Similarly, the findings regarding violating culture of thinking in this study provided students to insufficient and inappropriate contexts, inappropriate activity constructs, outdated activities, and insufficient instructions which may also limit students get familiarity with the thinking systems of the target language and have a negative effect on improving students' 
AJESI - Anadolu Journal of Educational Sciences International, 2020; 10(1): 583-628

DOI: 10.18039/ajesi.682060

thinking skills in the target language. The inappropriate and insufficient context may violate improving students' thinking skills in the target language since context provides a motivational and cognitive basis for language learning and offers the opportunity of getting familiarity with the cultural understanding of the target language (Snow, Met, \& Genesee, 1989). In this vein, especially the dimension of transfer should be promoted in the target textbooks to encourage students to raise their cultural awareness, and solving and adopting the systems of thinking in the target language. The activity types and instructions in the target textbooks may also limit students to construct a culture of thinking in the light of the characteristic thinking of the target language. Students may not have a whole understanding of the target language by giving them options to choose from. Also utilizing insufficient vocabulary of language of thinking or not giving detailed instructions for mental management and strategic spirit may discourage students to improve their thinking skills such as analysis, synthesis, and evaluation of the target language; and consequently, are restricted students to adopt the thinking system of the target language and construct a culture of thinking accordingly,

In this vein, second language textbooks should be revised to increase cultural awareness in the light of constructing a culture of thinking (Byram \& Feng, 2005). In the cross-cultural context, process-oriented tasks are suggested to promote cross-cultural adaptability (Wright, 2000), internet-based culture portfolios are utilized to promote cultural awareness (Abrams, 2002), interviews with native speakers' of target language are claimed to develop more positive attitudes toward the target culture (Bateman, 2002), drama is utilized to increase intercultural awareness and understanding (Choi, 2003), role-play activities are utilized to increase crosscultural awareness, and many other materials and techniques (e.g. readings, films, culture assimilators, simulation games, etc.) can be benefitted to help students increase their crosscultural awareness (Fantini, 1997; Ramirez, 1995; McGroarty \& Galvan, 1985). 
AJESI - Anadolu Journal of Educational Sciences International, 2020; 10(1): 583-628

DOI: 10.18039/ajesi.682060

As a result, it was explored that the target textbooks included such activities that to some extent promote the culture of thinking in terms of the language of thinking, mental management, the strategic spirit, and transfer. However, the findings regarding violating culture of thinking showed that the contexts, activity, and instructions in the target textbooks showed that they may restrict students to effectively construct a culture of thinking; therefore, the target textbooks are limited to promote the culture of thinking.

\section{Limitations and Implications}

Document analysis was conducted in the study with the aim of exploring how the $8^{\text {th }}$ grade ELT textbook contributes to the culture of thinking. In this vein, the most critical limitation is examining a textbook written by only a writer. In addition, examining the activities in a written textbook was another limitation for this study taking into account teachers have the most active role in improving the culture of thinking and the way teachers teach the textbook improves the culture of thinking more conveniently. In that regard, the materials are the supplementary documents. In this study, culture of thinking was studied assuming that the activities in the textbooks was taught directly with the way the target textbooks teach the activities. Conducting interviews and observations for how the textbooks teach would be more effective in exploring more authentic results in improving the culture of thinking.

The contexts and tasks assigned to the textbooks in English teaching are crucial for $21^{\text {st }}$ century skills to support and develop students' thinking processes such as critical thinking, creative thinking, problem-solving, cognitive awareness, and decision-making. The development of these processes is crucial for the English curriculum to serve the general objectives of the secondary school program. It is especially important not only for a thinking individual but also for creating a thinking school. In this context, it has been observed that 
AJESI - Anadolu Journal of Educational Sciences International, 2020; 10(1): 583-628

DOI: 10.18039/ajesi.682060

studies on the culture of thinking are limited. It is very important to conduct researches on the development of thinking processes and skills in English language teaching.

\section{References}

Abdul Shukor, A. (2001). Development of a learning and thinking society". Paper presented in an International Conference on Teaching and Learning in UKM [National University of Malaysia], Bangi, Selangor Darul Ehsan.

Abrams, Z. (2002). Surfing to cross cultural awareness: Using Internet-mediated projects to explore cultural stereotypes. Foreign Language Annuals, 35, 141-160.

Allwright, R. L. (1981). What do we want teaching materials for? ELT Journal, 36(1), 5-18.

Anderson, N.J. (2002). The role of metacognition in second language teaching and learning. ERIC Digest, April 2002, 3-4.

Apen, R. (2016). The applicative use of problem solving technique in teaching grammar. Proceedings of ISELT FBS Universitas Negeri Padang, 4(2), 180-187.

Assaly, I. R. \& Smadi, O. M. (2015) Using Bloom's taxonomy to evaluate the cognitive levels of master class textbook's questions. English Language Teaching, 8(5), 100-110.

Bateman, B. (2002). Promoting openness toward culture learning: Ethnographic interviews for students of Spanish. Modern Language Journal, 86, 318-331.

Bourke, J.M. (2004). Towards the design of a problem-solving programme of instruction for teaching English grammar to secondary-level ESL students. Journal of Applied Research in Education, 8, 104-122.

Bozorgian, H. (2014). The role of metacognition in the development of EFL learners' listening skill. International Journal of Listening, 28(3), 149-161.

Brown, H. D. (2007). Principles of language learning and teaching fifth edition. White Plains, NY: Pearson Education. 
AJESI - Anadolu Journal of Educational Sciences International, 2020; 10(1): 583-628

DOI: 10.18039/ajesi.682060

Byram, M. \& Feng, A. (2005). Teaching and researching intercultural competence. In E. Hinkel (Eds.) Handbook of research in second language teaching and learning (pp. 911-930). Mahwah, NJ: Lawrence Erlbaum Associates.

Chang, S.C. (2001). Implementation of the 'Thinking Schools, Learning Nation' initiative in Singapore. Journal of Southeast Asian Education, 2(1), 3-41.

Choi, Y-J. (2003). Intercultural communication through drama in teaching English as an international language. English Teaching, 28, 55-68.

Cohen, P. A., Kulik, J. A., \& Kulik, C. C. (1982). Educational outcomes of tutoring: A metaanalysis of findings. American Educational Research Journal, 19, 237-248

Cole, M., Engestrom, Y., \& Vasquez, O. (Eds.). (1997). Mind, culture, and activity: Seminal papers from the Laboratory of Comparative Human Cognition. Cambridge University Press.

Costa, A. L. (2008). Five themes to shape curriculum. Thought, 65(5), 20-24.

Costa, A. L., \& Marzano, R. J. (2001). Teaching the language of thinking. In A. Costa (Ed.), Developing minds: A resource bookfor teaching thinking. Alexandria, VA: Association for Supervision and Curriculum Development.

Cunningsworth, A. (1995). Choosing your coursebook. Oxford: Heinemann.

De Bono, E. (1983). The cognitive research trust (CoRT) thinking program. Thinking: The expanding frontier, 115-127.

Demir, S. (2008). An evaluation of thinking skills in ELT coursebooks at primary and secondary levels (Unpublished Master's Thesis). Çukurova University, Adana, Turkey.

Dilekli, Y., \& Tezci, E. (2016). The relationship among teachers' classroom practices for teaching thinking skills, teachers' self-efficacy towards teaching thinking skills and teachers' teaching styles. Thinking Skills and Creativity, 21, 144-151. 
AJESI - Anadolu Journal of Educational Sciences International, 2020; 10(1): 583-628

DOI: 10.18039/ajesi.682060

Doğanay, A. (1997). Ders dinleme sırasında bilişsel farkındalıkla ilgili stratejilerin kullanımı. Çukurova Üniversitesi Ë̆itim Fakültesi Dergisi, 2(15), 34-42.

Dole, S. F. (2017). Creating cultures of thinking: the 8 forces we must master to truly transform our schools. Interdisciplinary Journal of Problem-Based Learning, 11(2), 13.

Dubin. F. \& Olshtain, E. (1986). Course design. Developing programs and materials for language learning. Cambridge: Cambridge University Press.

Fantini, A. (1997). New ways of teaching culture. Alexandria, VA: Teachers of English to Speaking of other Languages.

Fantuzzo, J. W., Riggio, R. E., Connelly, S., \& Dimeff, L. A. (1989). Effects of reciprocal peer tutoring on academic achievement and psychological adjustment: A componential analysis. Journal of Educational Psychology, 81, 173-177.

Feuerstein, R. (1980). Instrumental enrichment: An intervention program for cognitive modifiability. Univ Park Pr.

Fisher, B. (1995). Thinking and learning together. Portsmouth, NH: Heinemann.

Flavell, J. H. (1976). Metacognitive aspects of problem solving. In L. B. Resnick (Ed.), The nature of intelligence (pp. 231-236). Hillsdale: Erlbaum.

Garner, R., \& Alexander, P. A. (1989). Metacognition: answered and unanswered questions. Educational Psychologist, 24, 143-158.

Golding, C. (2011). Educating for critical thinking: Thought-encouraging questions in a community of inquiry. Higher Education Research \& Development, 30(3), 357-370.

Griffiths, S., Houston, K., \& Lazenbatt, A. (1995). Enhancing Student Learning Through Peer Tutoring in Higher Education: A Compendium Resource Pack with Case Study Contributions. Implementing. University of Ulster.

Gushchin, A. (2015). "To teach learning..." or on the culture of thinking of today's students. Social and Behavioral Sciences, 214, p. 457-464. 
AJESI - Anadolu Journal of Educational Sciences International, 2020; 10(1): 583-628

DOI: 10.18039/ajesi.682060

Güss, C. D., \& Robinson, B. (2014). Predicted causality in decision making: the role of culture. Frontiers in Psychology, 5, 479.

Halpern, D. F. (2002). Teaching for critical thinking: A four-part model to enhance thinking skills. In S. F. Davis \& W. Buskist (Eds.), The teaching of psychology: Essays in honor of Wilbert J. McKeachie and Charles L. Brewer (pp. 91-105). Mahwah, NJ: Lawrence Erlbaum Associates

Halpern, D. F. (2003a). The "how" and "why" of critical thinking assessment. In D. Fasko (Ed.), Critical thinking and reasoning: Current research, theory and practice. Cresskill: Hampton Press.

Hei, J. X. (2017). Thinking skills in the 12th grade English course book in Timor Leste. Beyond Words, 5(1), 32-45.

Henderson, F., \& Wang, Y. (2014). Teaching content through moodle to facilitate students' critical thinking in academic reading. Asian EFL Journal, 16(3), 7-40.

Huberman, A. M., \& Miles, M. B. (1994). Data management and analysis methods. In N. K. Denzin \& Y. S. Lincoln (Eds.), Handbook of qualitative research (pp. 428-444). Thousand Oaks, CA, US: Sage Publications, Inc.

Hutchinson, T. (1987). What's underneath? An interactive view of materials evaluation. In L. E. Sheldon, (Ed.), ELT textbooks and materials: Problem in evaluation and development. ELT Documents 126 (pp. 37-44). London: Modern English Publications.

Inhelder, B. \& Piaget, J. (1958). The growth of logical thinking from childhood to adolescence. New York: Basic Books.

Ji, L. \& Yap, S. (2016). Culture and cognition. Current Opinion in Psychology, 8, 150.111.

Johnson, D. W., \& Johnson, R. T. (1986). Learning together and alone. Englewood Cliffs, NJ: Prentice Hall.

Karadüz, A. (2010). Dil becerileri ve eleştirel düşünme. Turkish Studies, 5(3), 1566-1593. 
AJESI - Anadolu Journal of Educational Sciences International, 2020; 10(1): 583-628

DOI: 10.18039/ajesi.682060

Karbalaei, A. (2011). Metacognition and reading comprehension. Íkala, revista de lenguaje y cultura, 16(28), 5-14.

Keith J. Topping \& Angela Bryce (2004) Cross-age peer tutoring of reading and thinking: influence on thinking skills. Educational Psychology, 24(5), 595-621,

Lakoff, G. (2004). Don't think of an elephant: Know your values and frame the debate. White River Junction, VT: Chelsea Green.

Larkin, S. (2009). Socially mediated metacognition and learning to write. Thinking Skills and Creativity, 4(3), 149-159.

Leat, D. (1999). Rolling the Stone Uphill: Teacher Development and the Implementation of Thinking Skills Programmes. Oxford Review of Education, 25(3), 387-403.

Levine, H. M., Glass, G. V., \& Meister, G. R. (1987). A cost-effectiveness analysis of computer-assisted instruction. Evaluation Review, 11, 50-72.

Li, L. (2016). Integrating thinking skills in foreign language learning: What can we learn from teachers' perspectives?. Thinking Skills and Creativity, 22, 273-288.

Lipman, M. (1982). Philosophy for children. Thinking: The Journal of Philosophy for children, 3(3/4), 35-44.

Litz, D. R. (2005). Textbook evaluation and ELT management: A South Korean case study. Asian EFL journal, 48, 1-53.

Mahdavi, M. (2014). An overview: Metacognition in education. International Journal of Multidisciplinary and current research, 2(3), 529-535.

Margana, M. \& Widyantoro, A. (2017). Developing English textbooks oriented to higher order thinking skills for students of vocational high schools in Yogyakarta. Journal of Language Teaching and Research, 8(1), 26-38.

Marzano, R. J. (1993). How classroom teachers approach the teaching of thinking. Theory into practice, 32(3), 154-160. 
AJESI - Anadolu Journal of Educational Sciences International, 2020; 10(1): 583-628

DOI: 10.18039/ajesi.682060

Marzano, R. J., \& Kendall, J. S. (2007). The new taxonomy of educational objectives. Thousand Oaks, CA: Corwin.

Marzano, R. J., Brandt, R. S., Hughes, C. S., Jones, B. F., Presseisen, B. Z., Rankin, S. C., \& Suhor, C. (1988). Dimension of Thinking. USA: Association for Supervision and Curriculum Developmen.

Matsumoto, D. (2000). Culture and psychology: People around the world. Belmont, CA: Wadsworth.

Mayer, R. E. (1998). Cognitive, metacognitive, and motivational aspects of problem solving. Instructional Science, 26, 49-63.

McGroarty, M. \& Galvan, J. (1985). Culture as an issue in second language teaching. In M. Celce-Murcia (Ed.), Beyond basics: Issues and research in TESOL (pp. 81-95). Cambridge, MA: Newbury House Publishers, Inc.

McGuinness, C. (1999). From thinking skills to thinking classrooms: A review and evaluation of approaches for developing pupils' thinking. London: Department for Education and Employment.

McGuinness, C. (2018). Informed Analysis of 21 st Century Competencies in a Redeveloped $\begin{array}{lll}\text { Primary } & \text { Curriculum. } & \text { Retrieved }\end{array}$ https://www.researchgate.net/profile/Carol_Mcguinness/publication/328421704_Rese arch Informed_Analysis_of $21 \_$st_Century_Competencies_in_a_Redeveloped _Primary_Curriculum_Final_Report_May_2018_2_NCCA_key_competencies_McGu inness_Final_Report/links/5bcdbdfc299bf17a1c667585/Research-Informed-Analysisof-21-st-Century-Competencies-in-a-Redeveloped-Primary-Curriculum-Final-ReportMay-2018-2-NCCA-key-competencies-McGuinness-Final-Report.pdf

Mercer, N., \& Littleton, K. (2007). Dialogue and the development of children's thinking: A sociocultural approach. Routledge. 
AJESI - Anadolu Journal of Educational Sciences International, 2020; 10(1): 583-628

DOI: 10.18039/ajesi.682060

Met, M. "Teaching Content Through a Second Language." (1994) In Genesee, F. (Eds.) Educating Second Language Children: The Whole Child, the Whole Curriculum, the Whole Community (pp. 159-182). Cambridge University Press, New York.

Mohammadi, M., \& Abdi, H. (2014). Textbook evaluation: A case study. Procedia-Social and Behavioral Sciences, 98, 1148-1155.

MoNE. (2018). Türkçe dersi ögrretim programı (ilkokul ve ortaokul 1, 2, 3, 4, 5, 6, 7 ve 8. sınıflar). Ankara: Millî Eğitim Bakanlığı Yayınları.

Najafi Sarem, S., Hamidi, H., \& Mahmoudie, R. (2013). A critical look at textbook evaluation: A case study of evaluating an ESP course-book: English for international tourism. International Research Journal of Applied and Basic Sciences, 4(2), 372-380.

Nguyen, L. T. C., \& Gu, Y. (2013). Strategy-based instruction: A learner-focused approach to developing learner autonomy. Language Teaching Research, 17(1), 9-30.

Nisbet, J. (1993). The thinking curriculum. Educational Psychology, 13(3-4), 281-290.

Nisbett, R. (2004). The geography of thought: How Asians and Westerners think differently... and why. New York, NY: Simon and Schuster.

Noor, B.M. (2009). Pedagogical issued in integrating thinking skills in the classroom. International Journal of Educational studies, 2(1), 55-67.

Norris, S. P. (1991). Assessment: Using verbal reports of thinking to improve multiple-choice test validity. In J. F. Voss, D. N. Perkins, \& J. W. Segal (Eds.), Informal reasoning and education (pp. 451-472). Hillsdale: Erlbaum.

Nuthall, G. (1999). Learning How To Learn: The Evolution of Students' Minds through the Social Processes and Culture of the Classroom. International Journal of Educational Research, 31(3), 141-256.

O’Neill, R. (1982). Why use textbooks?. ELT journal, 36(2), 104-111. 
AJESI - Anadolu Journal of Educational Sciences International, 2020; 10(1): 583-628

DOI: 10.18039/ajesi.682060

Özmen, K. S. (2008). Current state and understanding of critical thinking in higher education. GÜ, Gazi Ĕ̌gitim Dergisi, 28, 89-106.

Piaget, J. (1954). The construction of reality in the child. New York: Basic Books.

Piaget, J. (1972). Intellectual evolution from adolescence to adulthood. Human Development, $15,1-12$.

Piaget, J. (2002). The language and thought of the child. New York: Routledge.

Ramirez, A. (1995). Creating contexts for second language acquisition: Theory and methods. White Plains, NY: Longman.

Raoofi, S., Chan, S. H., Mukundan, J., \& Rashid, S. M. (2014). Metacognition and Second/Foreign Language Learning. English Language Teaching, 7(1), 36-49.

Reid, D.K. \& Hresko, W.P. (1982). Metacognition and learning disabilities. Oxford: Oxford University Press.

Resnick, L. B., \& Resnick, D. P. (1992). Assessing the thinking curriculum: New tools for educational reform. In Changing assessments (pp. 37-75). Springer, Dordrecht.

Richards, J. C. (2010). Competence and performance in language teaching. RELC Journal, $41(2), 101-122$.

Ritchhart, R. (2002). Intellectual character: What it is, why it matters, and how to get it. San Francisco: Jossey Bass.

Ritchhart, R. (2007). Cultivating a culture of thinking in museums. Journal of Museum Education, 32(2), 137-153.

Rogoff, B. (1990). Apprenticeship in thinking: Cognitive development in social context. Oxford university press.

Rohrbeck, C. A., Ginsburg-Block, M. D., Fantuzzo, J. W., \& Miller, T. R. (2003). Peer-assisted learning interventions with elementary school students: A meta-analytic review. Journal of Educational Psychology, 95, 240-257. 
AJESI - Anadolu Journal of Educational Sciences International, 2020; 10(1): 583-628

DOI: 10.18039/ajesi.682060

See, K.H. (1998). Peningkatan Daya Kreativiti Matematik Melalui Pembelajaran Berbantuan Komputer. Journal of Applied Research in Education, 2(1), 105-114.

Setyarini, S., Muslim, A. B., Rukmini, D., Yuliasri, I., \& Mujianto, Y. (2018). Thinking critically while storytelling: Improving children's HOTS and English oral competence. Indonesian Journal of Applied Linguistics, 8(1), 189-197.

Shardakova, M., \& Pavlenko, A. (2004). Identity options in Russian textbooks. Journal of Language, Identity and Education, 3(1), 25-46.

Sharpley, A. M., \& Sharpley, C. F. (1981). Peer tutoring: A review of the literature. Collected Original Resources in Education, 5(3), 7-C11.

Sheldon, L. E. (1988). Evaluating ELT textbooks and materials. ELT journal, 42(4), 237-246.

Sim, W.K. (2001). Some thoughts on 'Thoughtful Schools' in Brunei Darussalam. Journal of Southeast Asian Education, 2(1), 66-84.

Şimşek, (2017). Confronting culture in local and global English coursebooks: Student teachers’ preferences in materials adaptation. Journal of Theory and Practice in Education, 13(2), 277-300.

Şimşek, H., \& Yıldırım, A. (2011). Sosyal bilimlerde nitel araştırma yöntemleri. Ankara: Seçkin Yayıncılık.

Slavin, R. E. (1990). Co-operative learning: Theory, research and practice. Englewood Cliffs, NJ: Prentice Hall.

Smith, J. (2010). Talk, thinking and philosophy in the primary classroom. Learning Matters.

Snow, M. A., Met, M., \& Genesee, F. (1989). A conceptual framework for the integration of language and content in second/foreign language instruction. TESOL Quarterly, 23(2), 201-217. 
AJESI - Anadolu Journal of Educational Sciences International, 2020; 10(1): 583-628

DOI: 10.18039/ajesi.682060

Snow, M., Met, M., \& Genesee, F. (1989). A Conceptual Framework for the Integration of Language and Content in Second/Foreign Language Instruction. TESOL Quarterly, 23(2), 201-217. doi:10.2307/3587333.

Swartz, R. J., \& Parks, S. (1994). Infusing the Teaching of Critical and Creative Thinking into Content Instruction: A Lesson Design Handbook for the Elementary Grades. Critical Thinking Press and Software, PO Box 448, Pacific Grove, CA 93950-0448.

Tam, N. T. M. (2018). Using problem-based learning to promote students' use of higher-order thinking skills and facilitate their learning. VNU Journal of Foreign Studies, 34(2).

Teng, F. (2016). Immediate and delayed effects of embedded metacognitive instruction on Chinese EFL students' English writing and regulation of cognition. Thinking Skills and Creativity, 22, 289-302.

Tishman, S., Perkins, D., \& Jay, E. (1995). The thinking classroom: Learning and teaching in a culture of thinking. Boston: Allyn \& Bac.

Tok, H. (2010). TEFL textbook evaluation: From teachers' perspectives. Educational Research and Reviews, 5(9), 508.

Trickey \& K. J. Topping (2004) Philosophy for children: A systematic review. Research Papers in Education, 19(3), 365-380.

Vygotsky, L. (1934). 1962. Thought and language. Cambridge: MIT Press.

Vygotsky, L. S. (1994). The development of concept formation in adolescence. In R. van der Veer \& J. Valsiner (Eds.), The Vygotsky reader. Oxford: Blackwell.

Wardhough, R. (1976). The contexts of language. Rowley, MA: Newbury House.

Weber, E. U., \& Morris, M. W. (2010). Culture and judgment and decision making: The constructivist turn. Perspectives on Psychological Science, 5(4), 410-419. 
AJESI - Anadolu Journal of Educational Sciences International, 2020; 10(1): 583-628

DOI: 10.18039/ajesi.682060

Wegerif, R. (2006). A dialogic understanding of the relationship between CSCL and teaching thinking skills. International Journal of Computer-Supported Collaborative Learning, 1(1), 143-157.

Wegerif, R. (2010). Dialogue and teaching thinking with technology. In K. Littleton \& C. Howe (Eds.) Educational dialogues: Understanding and promoting productive interaction, 304. London and New York: Routledge.

Weinert, F.E. and R.H. Kluwe. (eds.) 1987. Metacognition, motivation and understanding. London: Lawrence Erlbaum Associates.

Wertsch, J. V. (1985). Vygotsky and the social formation of mind. Cambridge: Harvard University Press.

Whorf, B. (1956). Science and linguistics. In J. Carroll (Eds.), Language, thought, and reality: Selected writings of Benjamin Lee Whorf. Cambridge, MA: Massachusetts Institute of Technology Press.

Witkin, H. A., \& Berry, J. W. (1975). Psychological differentiation in cross-cultural perspective. ETS Research Bulletin Series, 1975(1), i-100.

Wright, D. (2000). Culture as information and culture as affective process: A comparative study. Foreign Language Annuals, 33, 330-341.

Yıldırım, A., \& Şimşek, H. (2013). Sosyal bilimlerde nitel araştırma yöntemleri. Ankara: Seçkin Yayıncılık,

Yong, C.S. (2003). Language problems in the learning of biology through the medium of English. Journal of Applied Research in Education, 7(1), 97-104.

Zohar, A. (2013). Challenges in wide scale implementation efforts to foster higher order thinking (HOT) in science education across a whole school system. Thinking Skills and Creativity, 10, 233-249. 
AJESI - Anadolu Journal of Educational Sciences International, 2020; 10(1): 583-628 DOI: 10.18039/ajesi.682060

Zohar, A., \& Cohen, A. (2016). Large scale implementation of higher order thinking (HOT) in civic education: The interplay of policy, politics, pedagogical leadership and detailed pedagogical planning. Thinking Skills and Creativity, 21, 85-96. 